\title{
NURSING HOME RESIDENTS MAKE A DIFFERENCE - \\ THE OVERESTIMATION OF SAVING RATES AT OLDER AGES
}

Michael Ziegelmeyer

(c) Mea-Mannheim Research Institute for the Economics of Aging 


\title{
Nursing home residents make a difference - The overestimation of saving rates at older ages ${ }^{1}$
}

\author{
Michael Ziegelmeyer ${ }^{\dagger}$ \\ This version: 28. November 2010
}

\begin{abstract}
While life-cycle theory makes the clear prediction that people dissave at old-age, this prediction is not at all borne out by the data from many countries. Various suggestions have been made to explain this discrepancy. This paper sheds more light on the effect of the exclusion of institutionalized individuals in estimating saving rates over old-age, a conceptual aspect often mentioned but never investigated. Particularly this group is expected to decumulate wealth since nursing home expenses net of private (and public) insurance exceed disposable income on average.

This paper uses data from the U.S. and Germany to show that there is an increasing overestimation of saving rates from age 75 on if institutionalized households are not included. The effect on aggregate saving rates caused by the exclusion of the nursing home population becomes even more important in the face of population aging. Specifically, this paper quantifies this effect using the Health and Retirement Study (HRS) for the USA. The overestimation of the mean (median) saving rates is 3.3 percentage points (4.3pp) at age 80, $5.4 \mathrm{pp}(9.4 \mathrm{pp})$ at age 90 and even more for age $90+$. Based on the German Income and Expenditure Survey (EVS), the overestimation of the German mean saving rate increases to almost 6pp at age 90. This strong overestimation is based on the fact that nursing home residents strongly reduced their wealth holdings. Referring to the USA, the median single nursing home resident reduces wealth holdings by $90 \%$ over a two-year period; the mean single nursing home resident diminishes total net wealth by $19 \%$. The dissaving is less strong for couples.
\end{abstract}

Keywords: nursing home population, saving, wealth, saving rate, saving puzzle, life-cycle models, elderly, age structure of the population

JEL: D12, D91, E21

\footnotetext{
${ }^{1}$ I would like to thank Axel Börsch-Supan (MEA), Michael Hurd (RAND), Michela Coppola (MEA), Daniel Schunk (Mainz University), Martin Gasche (MEA), Uli Schlieper (MEA), and Steffen Reinhold (MEA) for their helpful comments. I am grateful to the seminar participants at MEA for many useful comments. MEA is a research institute which is funded by two thirds through public third-party means for which I am very grateful. Furthermore, I would like to thank the state of Baden-Württemberg and the German Insurance Association for financing the basic funding of MEA.

$\dagger$ Mea, University of Mannheim, 68131 Mannheim, Germany; e-mail: ziegelmeyer@mea.uni-mannheim.de.
} 


\section{Introduction}

As suggested by the life-cycle-permanent income model (LCH-PIH model) developed by Modigliani and Brumberg (1954) and Friedman (1957), individuals should reduce their overall wealth holdings particularly during retirement to smooth consumption over their lifecycle. Empirical evidence ("International Saving Comparison Project"; Boersch-Supan et al., 2003) questions, at least in some countries, the prediction of dissaving during retirement since saving rates remain positive well beyond retirement. They find little evidence of wealth decumulation in old-age in Germany, France, Italy, the Netherlands, the U.K., and the USA, but they do find dissaving by retired individuals in Japan. New evidence (Horioka, 2009) finds even stronger dissaving for Japan. Making use of USA panel data, Hurd (1987) and Hurd and Rohwedder (2010) provide evidence for a reduction of wealth holdings for retired Americans.

Many suggestions were made to find an explanation for these empirical facts. ${ }^{2}$ I use a new and empirically well-founded approach to demonstrate why saving rates appear still positive or close to zero in old-age and quantify the contribution by estimating corrected saving rates including the institutionalized population. Authors of former studies argued that the inclusion of institutionalized elderly would not lead to a significant change in the results (e.g. Fall et al., 2001, p. 162). They are right when the population of interest is relatively young: the maximum age in the studies of the "International Saving Comparison Project" was 85 years, in most studies even below. I will show however that leaving out institutionalized elderly leads to a serious overestimation of the saving rate of the oldest old (75+) in the USA and Germany, since the institutionalized become increasingly important with age and precisely those individuals in nursing homes realize very high and negative saving rates. Excluding institutionalized individuals as done in the vast majority of the studies, may produce an increasingly selective sample over age.

The effect of the overestimation of saving rates by excluding institutionalized individuals is estimated for both the USA and Germany, two countries which differ in their arrangement of long-term care in nursing home. ${ }^{3}$ Even if the support of nursing home residents is stronger via the public long-term care insurance in Germany, the results are comparable in magnitude between these two countries.

\footnotetext{
${ }^{2}$ Some of them are briefly discussed in section 3 .

${ }^{3}$ See subsection 4.2 and 7.1 .2 for more details.
} 
This paper makes use of a well-established American dataset, the Health and Retirement Study (HRS) ${ }^{4}$. The dataset is set up in a way that individuals, who move to a nursing home, are sampled again. In addition, the dataset provides detailed information about wealth and other important characteristics.

The costs of living in a nursing home with its time intensive care for elderly people exceeds public pensions as well as public or private insurances on average (see Merlis, 2003, pp. 2227) for the USA. Thus, private savings are necessary to fill the gap between disposable income and nursing home costs. The paper has two main objectives:

1. I quantify the decrease of wealth holdings of institutionalized individuals using two different methods. Since nursing home expenses exceed disposable income for most of the individuals, nursing home residents will decrease their wealth faster compared to non-institutionalized individuals.

2. Based on these findings, I calculate the overestimation of saving rates at older ages if institutionalized individuals are not included in the sample.

The second objective is achieved by estimating saving rates using two different samples: the first one excludes the nursing home population, who are strongly dissaving (uncorrected saving rate); the second one includes nursing home residents (corrected saving rate). Comparing saving rates between these two samples allows estimating whether or not the exclusion of nursing home residents makes a difference in aggregate saving rates in old-age.

Evidence based on the HRS suggests that nursing home residents and the risk of long-term care in a nursing home are key components in understanding the saving behavior in old-age. Depending on how the dissaving is measured (ratio of means, ratio of medians, median of individual changes) $)^{5}$, it takes between 2 and 11 years for single nursing home residents to eat up all their wealth in the USA. Couples, who have at least one nursing home resident, dissave less strongly. This is the reason why 44\% [35\%] of all nursing home expenses have to be financed by Medicaid in 1996 [2004] (Rhoades and Sommers, 2000; CBO, 2004), which supports individuals and families who cannot afford living in a nursing home any more. Since the nursing home population almost increases exponentially with age and reaches more than $30 \%$ around age 95 for the USA, leaving out nursing home residents leads to a serious overestimation of the aggregate saving rates in old-age. According to my estimates, not including the institutionalized households results in an overestimation of the mean (median)

\footnotetext{
${ }^{4}$ The HRS (Health and Retirement Study) is sponsored by the National Institute on Aging (grant number NIA U01AG009740) and is conducted by the University of Michigan.

${ }^{5}$ See subsection 6.1 for further details.
} 
saving rates by $3.3 \mathrm{pp}(4.3 \mathrm{pp})$ at age $80,5.4 \mathrm{pp}(9.4 \mathrm{pp})$ at age 90 and even more for age $90+$. The results demonstrate the serious bias of the saving rates of the elderly as a result of not including institutionalized households.

Germany, which is one of the countries with the highest positive saving rates in old-age, is analyzed to compare the results obtained from the USA. A detailed calculation accounting for the German institutional setting is accomplished based on the German Income and Expenditure Survey (EVS). Despite quite generous social long-term care contributions, the overestimation of the mean saving rate increases to around 6pp at age 90. Therefore, the overestimation of saving rates is not restricted to the USA and is even comparable in its magnitude.

This study makes one key contribution to the literature. As presented in section 2, micro data show at most zero or small positive saving rates in old-age for most of the countries. By quantifying the wealth decumulation of the nursing home population and comparing the saving rates between non-institutionalized elderly and all elderly (including institutionalized individuals), the paper clarifies the overestimation of aggregate saving rates of micro data by leaving out the fraction of the population that strongly dissaves. ${ }^{6}$

The paper stresses the importance of including the institutionalized population when conducting empirical investigations about life-cycle saving behavior. The number of U.S. resident population over the age of 85 is estimated to be around 5.6 million on July, 2009 (U.S. Census Bureau, Population Division, 2010). For individuals 85 and older long-term care in nursing homes is quite prevalent. Based on projections the 85 year olds increase to over 20 millions in 2050 (Oxford Analytica, 2007). Thus, the bias induced on aggregate saving rates by excluding the institutionalized population will increase over time.

The outline of the paper is as follows: Section 2 summarizes the empirical evidence of saving rates and wealth decumulation of elderly individuals in different countries. This section reviews the datasets on which the analyses are based, and whether or not the nursing home population is included in the datasets used. Section 3 provides an overview of approaches from statistics and economics to solve the "saving puzzle" of the elderly. An overview of the

\footnotetext{
${ }^{6}$ This reduces saving rates in old-age in a way that the saving rates might be plausible from a perspective of an extended life-cycle model, which includes health and long-term care payments and risk in the optimization problem (a brief discussion of these models can be found in section 3).
} 
institutional backgrounds related to long-term care and how long-term care is financed in the USA is given in section 4. The dataset used in the analysis is described in section 5, and descriptive statistics about the nursing home population are introduced. The results are presented in section 6. Section 7 provides a calculation to quantify the bias of German saving rates at older ages. Section 8 concludes.

\section{Empirical evidence about the saving rate of the elderly}

Table 1 displays empirical evidence about the saving behavior of the elderly in different countries. ${ }^{7}$ Appendix A outlines different concepts to measure saving and summarizes briefly their advantages and disadvantages.

\section{Table 1: Literature overview}

\begin{tabular}{|c|c|c|c|c|c|c|c|}
\hline 总 & 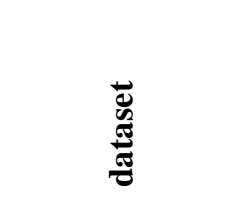 & 总: & 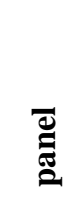 & 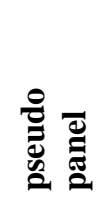 & 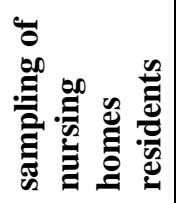 & 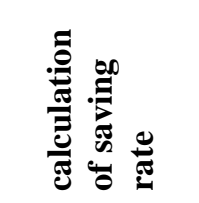 & 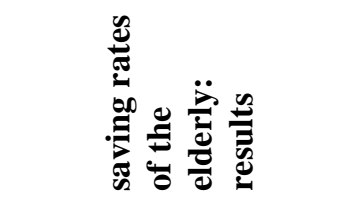 \\
\hline \multirow[t]{2}{*}{$\begin{array}{l}\text { France (Fall et } \\
\text { al., 2001) }\end{array}$} & $\begin{array}{l}\text { the Household } \\
\text { Budget } \\
\text { Surveys (HBS) }\end{array}$ & $\begin{array}{l}1984, \\
1989, \\
1995\end{array}$ & No & Yes & No & $\begin{array}{l}\text { income } \\
\text { minus } \\
\text { consumption }\end{array}$ & $\begin{array}{l}\text { positive mean saving } \\
\text { rate; between a quarter } \\
\text { and a third of } \\
\text { households had } \\
\text { negative or zero } \\
\text { savings }\end{array}$ \\
\hline & $\begin{array}{l}\text { the Financial } \\
\text { Assets Surveys } \\
\text { (FAS) }\end{array}$ & $\begin{array}{l}1986, \\
1992, \\
1998\end{array}$ & No & Yes & No & $\begin{array}{l}\text { changes in } \\
\text { wealth }\end{array}$ & $\begin{array}{l}\text { average total saving } \\
\text { positive at complete } \\
\text { time period; active } \\
\text { financial saving } \\
\text { becomes very low } \\
\text { from age } 70 \text { on }\end{array}$ \\
\hline \multirow{2}{*}{$\begin{array}{l}\text { Germany } \\
\text { (Börsch-Supan } \\
\text { et al., 2003) }\end{array}$} & \multirow{2}{*}{$\begin{array}{l}\text { the German } \\
\text { Income and } \\
\text { Expenditure } \\
\text { Survey (EVS) }\end{array}$} & \multirow{2}{*}{$\begin{array}{l}1978, \\
1983, \\
1988, \\
1993\end{array}$} & \multirow[t]{2}{*}{ No } & \multirow[t]{2}{*}{ Yes } & \multirow[t]{2}{*}{ No } & $\begin{array}{l}\text { changes in } \\
\text { wealth }\end{array}$ & $\begin{array}{l}\text { positive mean and } \\
\text { median saving rates }\end{array}$ \\
\hline & & & & & & $\begin{array}{l}\text { income } \\
\text { minus } \\
\text { consumption }\end{array}$ & $\begin{array}{l}\text { positive mean and } \\
\text { median saving rates }\end{array}$ \\
\hline \multirow[t]{2}{*}{$\begin{array}{l}\text { Italy } \\
\text { (Brugiavini } \\
\text { and Padula, } \\
\text { 2003) }\end{array}$} & \multirow{2}{*}{$\begin{array}{l}\text { the Survey of } \\
\text { Household } \\
\text { Income and } \\
\text { Wealth } \\
\text { (SHIW) }\end{array}$} & \multirow{2}{*}{$\begin{array}{l}1984, \\
1986, \\
1987, \\
1989, \\
1991, \\
1993, \\
1995, \\
1997\end{array}$} & No & Yes & \multirow[t]{2}{*}{ No } & $\begin{array}{l}\text { income } \\
\text { minus } \\
\text { consumption }\end{array}$ & $\begin{array}{l}\text { mean and median } \\
\text { discretionary saving } \\
\text { rates remain positive in } \\
\text { old-age }\end{array}$ \\
\hline & & & Yes & No & & $\begin{array}{l}\text { changes in } \\
\text { wealth }\end{array}$ & $\begin{array}{l}\text { median real wealth } \\
\text { declines with age, for } \\
\text { the mean real wealth } \\
\text { evidence is mixed }\end{array}$ \\
\hline
\end{tabular}

\footnotetext{
${ }^{7}$ The table has no claim to be complete. It should rather give an impression about the literature.
} 


\begin{tabular}{|c|c|c|c|c|c|c|c|}
\hline $\begin{array}{l}\text { Japan } \\
\text { (Kitamura et } \\
\text { al., 2003) }\end{array}$ & $\begin{array}{l}\text { the National } \\
\text { Survey of } \\
\text { Family Income } \\
\text { and } \\
\text { Expenditures } \\
\text { (NSFIE) }\end{array}$ & $\begin{array}{l}1984, \\
1989, \\
1994\end{array}$ & No & Yes & No & $\begin{array}{l}\text { income } \\
\text { minus } \\
\text { consumption }\end{array}$ & $\begin{array}{l}\text { total median saving } \\
\text { rate negative above } 70 ; \\
\text { average of individual } \\
\text { saving rate negative } \\
\text { from age } 60 \text { on }\end{array}$ \\
\hline $\begin{array}{l}\text { Japan } \\
\text { (Horioka, } \\
2009 \text { ) }\end{array}$ & $\begin{array}{l}\text { the National } \\
\text { Survey of } \\
\text { Family Income } \\
\text { and } \\
\text { Expenditures } \\
\text { (NSFIE) }\end{array}$ & $\begin{array}{l}1995- \\
2008\end{array}$ & No & Yes & No & $\begin{array}{l}\text { income } \\
\text { minus } \\
\text { consumption }\end{array}$ & $\begin{array}{l}\text { the retired elderly } \\
\text { dissave; the dissaving } \\
\text { increases during the } \\
\text { investigation period }\end{array}$ \\
\hline \multirow[t]{2}{*}{$\begin{array}{l}\text { the } \\
\text { Netherlands } \\
\text { (Alessie and } \\
\text { Kepteyn, } \\
\text { 2003) }\end{array}$} & $\begin{array}{l}\text { the Socio- } \\
\text { Economic } \\
\text { Panel (SEP) }\end{array}$ & $\begin{array}{l}1988, \\
1992, \\
1996\end{array}$ & Yes & No & No & $\begin{array}{l}\text { changes in } \\
\text { wealth }\end{array}$ & $\begin{array}{l}\text { median saving rate } \\
\text { close to zero in old- } \\
\text { age; at least } 50 \% \text { of the } \\
\text { households do not } \\
\text { dissave during } \\
\text { retirement }\end{array}$ \\
\hline & $\begin{array}{l}\text { the Dutch } \\
\text { Consumer } \\
\text { Expenditure } \\
\text { Survey (CES) }\end{array}$ & $\begin{array}{l}1985, \\
1990, \\
1995\end{array}$ & No & Yes & No & $\begin{array}{l}\text { income } \\
\text { minus } \\
\text { consumption }\end{array}$ & $\begin{array}{l}\text { median saving rate } \\
\text { positive in old-age and } \\
\text { increasing towards the } \\
\text { end of life }\end{array}$ \\
\hline $\begin{array}{l}\text { United } \\
\text { Kingdom } \\
\text { (Banks and } \\
\text { Rohwedder, } \\
\text { 2003) }\end{array}$ & $\begin{array}{l}\text { the Family } \\
\text { Expenditure } \\
\text { Survey (FES) }\end{array}$ & $\begin{array}{l}1974- \\
1995\end{array}$ & No & Yes & No & $\begin{array}{l}\text { income } \\
\text { minus } \\
\text { consumption }\end{array}$ & $\begin{array}{l}\text { median household } \\
\text { savings positive in old- } \\
\text { age, median saving } \\
\text { ratio increases with age }\end{array}$ \\
\hline $\begin{array}{l}\text { USA } \\
\text { (Hurd, 1987) }\end{array}$ & $\begin{array}{l}\text { the } \\
\text { Longitudinal } \\
\text { Retirement } \\
\text { History Survey } \\
\text { (RHS) }\end{array}$ & $\begin{array}{l}1969, \\
1971, \\
1973, \\
1975, \\
1977, \\
1979\end{array}$ & Yes & No & No & $\begin{array}{l}\text { changes in } \\
\text { wealth }\end{array}$ & $\begin{array}{l}\text { both couples and } \\
\text { singles dissave in old- } \\
\text { age; the dissaving is } \\
\text { less strong for couples }\end{array}$ \\
\hline \multirow[t]{2}{*}{$\begin{array}{l}\text { USA } \\
\text { (Attanasio and } \\
\text { Paiella, 2003) }\end{array}$} & \multirow[t]{2}{*}{$\begin{array}{l}\text { the USA } \\
\text { Consumer } \\
\text { Expenditure } \\
\text { Survey (CEX) }\end{array}$} & \multirow[t]{2}{*}{$\begin{array}{l}1982- \\
1995\end{array}$} & \multirow{2}{*}{ 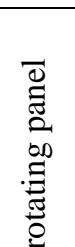 } & \multirow[t]{2}{*}{ Yes } & \multirow[t]{2}{*}{ No } & $\begin{array}{l}\text { adding } \\
\text { individual } \\
\text { saving } \\
\text { components } \\
\end{array}$ & $\begin{array}{l}\text { median financial } \\
\text { savings appears to } \\
\text { become negative at the } \\
\text { end of the life-cycle }\end{array}$ \\
\hline & & & & & & $\begin{array}{l}\text { income - } \\
\text { consumption }\end{array}$ & $\begin{array}{l}\text { median saving remains } \\
\text { positive in old-age }\end{array}$ \\
\hline \multirow[t]{2}{*}{$\begin{array}{l}\text { USA } \\
\text { (Hurd and } \\
\text { Rohwedder, } \\
\text { 2010) }\end{array}$} & $\begin{array}{l}\text { Health and } \\
\text { Retirement } \\
\text { Study (HRS) }\end{array}$ & $\begin{array}{l}1996- \\
2008\end{array}$ & Yes & No & Yes & $\begin{array}{l}\text { changes in } \\
\text { wealth }\end{array}$ & $\begin{array}{l}\text { dissaving observed for } \\
\text { singles, the effect is } \\
\text { much smaller for } \\
\text { couples }\end{array}$ \\
\hline & $\begin{array}{l}\text { Consumption } \\
\text { and Activities } \\
\text { Mail Survey } \\
\text { (CAMS) of the } \\
\text { HRS }\end{array}$ & $\begin{array}{l}2001, \\
2003, \\
2005, \\
2007\end{array}$ & Yes & No & Yes & $\begin{array}{l}\text { income } \\
\text { minus } \\
\text { consumption }\end{array}$ & $\begin{array}{l}\text { small dissaving } \\
\text { observed for singles, } \\
\text { wealth increases } \\
\text { observed for couples }\end{array}$ \\
\hline
\end{tabular}

As can be seen, most of the studies rely on pseudo panel data. In most of these studies the evidence about dissaving in old-age is small. In Italy, the residual saving rate measure declines with age but remains positive. In France, Germany, the Netherlands, and the U.K. the residual saving rate actually does not decline with age. Only in the case of Japan and USA (Hurd and Rohwedder, 2010), residual saving becomes negative in old-age. Evidence based on changes in wealth differs from the residual measure in some countries. Especially in the 
Netherlands, Italy, and the USA, wealth holdings decline with age. The evidence on wealth changes in these countries is based on real panel data. Hurd (1990, pp. 582-584, 611-614) shows clearly the bias of inference based on cross-sectional data due to differential mortality and emphasizes the importance of long panel data. Thus, measurement error related to the two saving measures as well as differential mortality might explain the different results related to the validity of the life-cycle model in old-age.

In all the datasets introduced above with only one exception (Hurd and Rohwedder, 2010), institutionalized individuals are not covered in the sample and the maximum age included in the studies is at most 85 years. Before discussing the institutional background of long-term care, the financing of long-term care, and the fraction of nursing home residents over age in the USA, section 3 discusses possible solutions to the empirical puzzle presented in section 2.

\section{Possible explanations for the puzzle of still positive saving rates in old- age}

Many suggestions were made to find an explanation to these empirical facts. On the one side the empirical facts could be the results of other economic saving motives, e.g. the bequest motive (Hurd, 1987, 1989) or the precautionary saving motive (Yaari, 1965; Palumbo, 1999), which can be included in the LCH-PIH model. A relatively new branch of literature incorporates health and long-term care payments and risk in the estimation of their structural life-cycle models, pointing out the relevance of long-term care expenses in understanding the saving behavior in old-age (Brown and Finkelstein, 2008; De Nardi, French, and Jones, 2010; Ameriks, Caplin, Laufer, and Van Nieuwerburgh, 2010). All the models have in common that they model the intertemporal decision process of a retired single with heterogeneous life expectancy. The agent faces risky and heterogeneous medical expenditures including longterm care. The risk and the associated expenditures related to long-term care are substantial in all three models. Brown and Finkelstein (2008) estimate from the National Nursing Home Study and the longitudinal National Long Term Care Survey that the probabilities of ever using a nursing home are $27 \%$ for 65 -year-old men and $44 \%$ for 65 -year-old women. De Nardi, French, and Jones (2010) calculate mean medical expenses over age and income quintiles from the AHEAD survey. Medical expenses sharply increase with age from less than $\$ 1,000$ p.a. at age 75 to $\$ 17,700$ p.a. at age 100 . At age $100,72 \%$ of the medical expenses are 
nursing home costs. Marshall, McGarry, and Skinner (2010) estimate the distribution of outof-pocket medical expenditures in the last year of life. Their average estimate is $\$ 11,618$, the 90th percentile has expenses of $\$ 29,335$, and 95 th percentile of $\$ 49,907 .^{8}$

Börsch-Supan and Stahl (1991) suggest that the low level of wealth decumulation in old-age is caused by the deteriorating health status of the elderly and the generous German pension system combined with the almost complete coverage of health expenses by the mandatory German health insurance. The deteriorating health status may prevent the elderly from spending more than their disposable income, and this leads to a deviation from optimal lifecycle behavior.

On the other side statistical artifacts are an important part of the explanation. Saving behavior differs strongly depending on the political and economic conditions individuals grow up in. Among other studies, the "International Saving Comparison Project" (Börsch-Supan et al., 2003) showed how crucial it is to control cohort effects. Most studies rely on synthetic panel data to estimate the effect of age on the saving rate. As the poor face higher mortality rates, the wealth holdings of older cohorts are biased upwards. Thus, in synthetic panels one has to take differential mortality into account (Shorrocks, 1975; Hurd, 1987, 1990; Jianakoplos et al., 1989; Attanasio and Hoynes, 2000).

An additional explanation is related to an increasingly selective sample because nursing home residents are not sampled in almost all studies introduced in section 2. Since the nursing home population increases with age and is expected to strongly dissave, saving rates are overestimated. Before exploiting this aspect, the next section provides the institutional background of long-term care, selected statistics, and information about the financing of longterm care in the USA.

\footnotetext{
${ }^{8}$ The structural life-cycle models focus on different empirical facts they want to explain. Brown and Finkelstein (2008) explain the lack of private insurance purchases by the large crowd-out effect of Medicaid. Ameriks, Caplin, Laufer, and Van Nieuwerburgh (2010) provide evidence that the lack of wealth decumulation in old-age is driven by public care aversion and a bequest motive, which is not only important for wealthy households but also for the middle class. De Nardi, French, and Jones (2010) find that medical expenditures play an important role in explaining the saving behavior in old-age over different income groups.
} 


\section{Institutional backgrounds related to long-term care and how long-term care is financed in the USA}

\subsection{Resident characteristics}

The fraction of nursing home population increases strongly with age (figure 1). Only $1.25 \%$ of individuals aged 70 live in nursing homes. This fraction increases to $2.5 \%$ for individuals aged $75,5 \%$ for those aged $80,15 \%$ for those aged 85 , and almost $30 \%$ for those aged 90 . It seems that the percentage of nursing home residents doubles every 5 years from age 70 on.

\section{Figure 1: Institutionalized population over age groups in the USA}

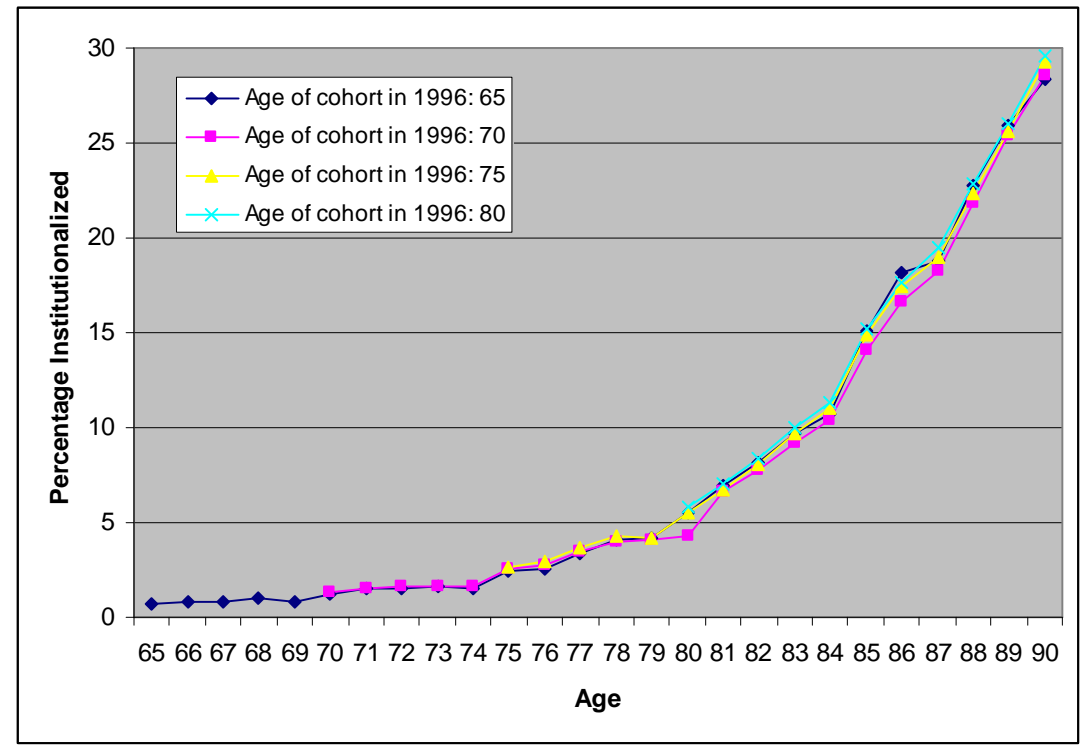

Source: Lakdawalla et al. (2003), Baseline Forecasts of Changes in Nursing Home Use, table 3, p. 15.

Data from a nationally representative sample of nursing homes and nursing home residents from 1996 (Nursing Home Component (NHC) of the Medical Expenditure Panel Survey (MEPS)) show that more than two-thirds of the nursing home population in $1996(71.6 \%)$ are women (Krauss and Altman, 1998). Most of the residents are already widowed (59.8\%). $16.6 \%$ of residents are married and $14.4 \%$ have never been married. The remaining residents (9.2\%) are divorced or separated. Compared to 2004, the resident characteristics did not change that much. Based on the National Nursing Home Survey, Jonas et al. (2009) report $71.2 \%$ female residents. $54.1 \%$ of the respondents are widowed, $20.5 \%$ are married or living with a partner, $15.1 \%$ are single or never married, and $10.3 \%$ are divorced or separated. 


\subsection{How is long-term care financed?}

For all the individuals without the means of financing nursing home costs, the expenses of assessed need are financed by Medicaid, the health program for individuals and families with low incomes and resources, which is jointly funded by the federal and state governments through general taxation. Since Medicaid is a means-tested payer of last resort, all individuals who can afford it have to pay long-term care expenses in institutions net of private insurance. If a household has more income and assets than Medicaid allows, the household has to pay for long-term care until income and assets are at or below states poverty level. Medicaid is not limited to a certain time period as long as the individuals meet the qualification based on need for care and financial need. The spouse of a Medicaid recipient is permitted to keep a low level of disposable income and certain assets, like the ownership of a home and a car, in order to avoid poverty. Any amount above the level has to be spent for the institutionalized spouses' care. ${ }^{9}$ An additional source of financing long-term care is Medicare, a social insurance program, which is funded by the Federal government through social security contributions. Medicare covers mainly short-term nursing home stays for people to recover from acute illness (OECD, 2005). Individuals have to be approved to get Medicare coverage for a nursing home stay: First, one has to have been in the hospital for at least three days prior to entering the nursing home. Second, skilled nursing is needed. Custodial care like help with activities of daily living such as eating, bathing and dressing is not covered. Another payment source is the private long-term care insurance. However, the ownership rates of such kind of insurance among individuals 60 years and older is only around 10\% (Brown and Finkelstein, 2007). ${ }^{10}$

In 1996 around $\$ 70$ billion ( $0.9 \%$ of GDP) were spent on expenses for services in nursing homes on a national level (Rhoades and Sommers, 2000) compared to \$135 billion (1.1\% of

\footnotetext{
${ }^{9}$ A concern is that individuals hide assets from Medicaid or transfer assets to other households in order to protect resources for the individual and/or heirs. Medicaid eligibility rules impose penalties on individuals who give their assets away over a three- to five-year look-back period on assets prior to application (Stone, 2002).

${ }^{10}$ Merlis (2003) points out several reasons why individuals do not purchase private long-term care insurance despite they can afford it. Young individuals postpone the decision about private long-term care insurance since many of them face other and more urgent financial risks. In addition, the environment, personal and institutional circumstances can change until the nursing home stay becomes relevant. Savings might be the more flexible instrument. Older individuals are more likely to fail specified underwriting screens to be allowed to purchase long-term care insurance. Moreover, insurance premiums strongly increase with age, and a larger fraction of elderly might not be able to finance private long-term care insurance anymore. Brown and Finkelstein (2008) add that Medicaid crowds out the purchase of a private insurance for the bottom two-thirds of the wealth distribution. This is due to the fact that despite the limited coverage of Medicaid, Medicaid is means-tested after taking private insurance into account.
} 
GDP) in 2004 (CBO, 2004). The aggregate long-term care expenditures have the following structures in 1996 and in 2004 [in brackets]: 44\% [35\%] were financed by Medicaid, 30\% [33\%] were out-of-pocket expenditures paid from social security or pension income, other income, assets, or financial support of the family, 19\% [25\%] were covered by Medicare, $4 \%$ [4\%] by private insurance, and 3\% [3\%] by other sources (Department of Veterans Affairs, health maintenance organization contract, or other). Only 30\% [33\%] is financed by disposable income and wealth. The large fraction financed by Medicaid suggests that there are many individuals who never had enough income and/or wealth or who already decumulated their wealth to finance their nursing home expenses. ${ }^{11}$

\section{Data}

\subsection{Health and Retirement Study (HRS)}

The HRS is a representative U.S. American panel survey of individuals aged 51 and above and their spouses. The empirical analysis is based on the RAND HRS Data. This file is an easy-to-use dataset, which is already cleaned and edited across waves. I use the following waves to conduct my analysis: ${ }^{12}$ 1996, 1998, 2000, 2002, 2004, 2006 and $2008^{13}$.

The wealth measure used is total net wealth (excluding secondary residence) ${ }^{14}$, which is available in all the years named above. Wealth is inflation adjusted, and the base year is 2000 . From 1996 forward, some variables provide information about nursing home residence. ${ }^{15}$ In the HRS ${ }^{16}$ nursing homes are defined as: "Nursing homes are institutions primarily for people

\footnotetext{
${ }^{11}$ Despite the fact that Medicaid steps in as a means-tested payer of last resort, there are reasons why an individual could try to prevent publicly-provided long-term care. Ameriks, Caplin, Laufer, and Van Nieuwerburgh (2010) use the term public care aversion. Public care aversion could be the result of Medicaid's restrictions in the choice of facility, quality differential between Medicaid-financed and privately financed care or perceived quality differences (Norton (2000) provides a review of the mixed empirical evidence), surrender of almost all income to the government, or feeling some stigma associated with Medicaid.

${ }^{12}$ I exclude the all observations of wave 2 since assets were underreported in 1994 (1993) wave of AHEAD (Rohwedder, Haider, and Hurd, 2004).

${ }^{13}$ The RAND HRS Data (Version J) uses Early Release data from the Health and Retirement Study in 2008, sponsored by the National Institute on Aging (grant number NIA U01AG009740) and conducted by the University of Michigan. These data have not been cleaned and may contain errors that will be corrected in the Final Public Release version of the dataset. All the other waves of the RAND HRS Data (Version J) are not Early Release data.

${ }^{14}$ The reason why the value of secondary residence is excluded is that the value of secondary residence is not available in wave 3 . An overview of the asset categories included in the wealth measure used can be found in Appendix D.

${ }^{15}$ The variable used indicates whether the respondent lives in a nursing home at the time of the interview.

${ }^{16}$ The definition is taken out the HRS questionnaires. The definition is the same over all wave from 1996 to 2008.
} 
who need constant nursing supervision or are incapable of living independently. Nursing supervision must be provided on a continuous basis for the institution to qualify as a nursing home. Please don't include stays in adult foster care facilities or other short-term stays in a hospital."17

Respondents below 65 years are excluded because this paper focuses on the saving rates from age 65 on. Table 12 in Appendix B provides all details about the sample restriction. Tables and results in section 5 and 6 are weighted if not stated otherwise. Appendix C informs about the weights and how they are constructed. ${ }^{18}$ The accurate measurement of wealth is crucial for this analysis. A justified concern is that nursing home residents are less informed about their wealth holdings due to cognitive restrictions they might face in their condition. One would expect that more wealth categories have to be imputed for nursing home residents. Table 13 (Appendix D) provides details about item non-response over all wealth categories necessary to construct total net wealth (excluding secondary residence). Over most of the wealth categories institutionalized individuals have even lower missing rates. ${ }^{19}$

Table 2 displays the sample size of respondents and the fraction of respondents currently living in a nursing home over different age groups. Over all years 2,872 observations of current nursing home residents are available. This reflects $3.8 \%$ of the sample of around 74,664 respondents. The second part of table 2 excludes non retired individuals, because their saving behavior differs from that of retired individuals. ${ }^{20}$ The LCH-PIH model predicts negative saving rates for retired individuals, so many studies focus on these. In this study I focus on all individuals of age 65 and above because aggregated saving rates over all individuals for each age should be calculated. Excluding non-retired individuals reduces the samples size especially for younger ages of non-institutionalized individuals (table 2). The

\footnotetext{
${ }^{17}$ This corresponds quite closely to a definition of Gilberg (2000, pp. 59-60) and Ribbe et al. (1997, pp. 5-7): “A nursing home is an institution for elderly people who are not able to independently take care of their household any more. The nursing home provides room, food and assistance (e.g. cleaning of rooms and clothes). In addition, nursing homes are institutions providing nursing care $24 \mathrm{~h}$ a day for all residents necessary. This includes assistance with activities of daily living and mobility, psychosocial and personal care, paramedical care, such as physiotherapy and occupational therapy."

Nursing homes have to be separated from residential homes, which are not the focus of this study and are defined as follows: "Residential homes for the elderly (or home for the aged) are institutions for elderly who are still able to independently keep their house. They provide living conditions adjusted to the needs of their elderly residents. The resident requires no more nursing care than given by a visiting nurse. Ambulatory services are provided by some of the residential homes."

${ }^{18}$ The unweighted results differ only slightly from the weighted results presented in this paper. The unweighted results are available upon request.

${ }^{19}$ One reason for this might be that proxies (relatives like children) are better informed about the wealth holdings of their parents. The number of proxy interviews increases from $7 \%$ at age 65 , to $11 \%$ at age 80 , to $23 \%$ at age 90 , to $46 \%$ at age 95 and above.

${ }^{20}$ Excluding non-retired individuals does not change the evidence in section 6.
} 
sample size for the institutionalized individuals remains almost unchanged (the difference is less than $1 \%$ ).

Whereas the number of all observation decreases with age (table 2), the number of nursing home residents increases for higher age groups. The percentage of nursing home residents based on the National Nursing Home Survey (NNHS) in 2004 (Jones et al., 2009) is relatively similar to the HRS. Whereas the difference for the oldest age group is significantly larger in the HRS compared to the NNHS, for age groups $65-74$ and 75-84 no significant difference is observed. The gender composition (table 3 ) in nursing homes, household composition (table 4), and race (table 5) almost exactly mirrors the National Nursing Home Survey of 2004.

Table 2: Sample size - number of respondents over age groups

\begin{tabular}{|c|c|c|c|c|c|c|c|}
\hline \multirow[b]{2}{*}{ age } & \multicolumn{3}{|c|}{ working and retired individuals } & \multicolumn{3}{|c|}{ exclude non-retired individuals } & \multirow{2}{*}{$\begin{array}{r}\text { The National } \\
\text { Nursing Home } \\
\text { Survey - 2004 }\end{array}$} \\
\hline & $\begin{array}{r}\text { \# all } \\
\text { respondents } \\
\end{array}$ & $\begin{array}{l}\text { \# living in a } \\
\text { nursing home }\end{array}$ & $\begin{array}{r}\text { living in a nursing } \\
\text { home in } \% \text { of age group }\end{array}$ & $\begin{array}{r}\text { \# all } \\
\text { respondents }\end{array}$ & $\begin{array}{l}\text { \# living in a } \\
\text { nursing home }\end{array}$ & $\begin{array}{r}\text { living in a nursing } \\
\text { home in } \% \text { of age group }\end{array}$ & \\
\hline 65-69 & 20,993 & 138 & $0.7 \%$ & 17,831 & 136 & $0.8 \%$ & $0.9 \%$ \\
\hline $70-74$ & 18,178 & 223 & $1.2 \%$ & 16,891 & 220 & $1.3 \%$ & \\
\hline $75-79$ & 14,905 & 348 & $2.3 \%$ & 14,359 & 347 & $2.4 \%$ & 36 \\
\hline $80-84$ & 10,844 & 556 & $5.1 \%$ & 10,654 & 555 & $5.2 \%$ & $3.0 \%$ \\
\hline $85+$ & 9,744 & 1,607 & $16.5 \%$ & 9,670 & 1,601 & $16.6 \%$ & $14.4 \%$ \\
\hline total & 74,664 & 2,872 & $3.8 \%$ & 69,405 & 2,859 & $4.1 \%$ & $3.6 \%$ \\
\hline
\end{tabular}

Source: own calculations based on RAND HRS Data 1996-2008 (Version J); National Nursing Home Survey 2004 (Jones et al., 2009, table 5).

Table 3: Nursing home residence over gender

\begin{tabular}{|c|c|c|c|c|}
\hline gender & $\begin{array}{r}\text { not } \\
\text { institutionalized }\end{array}$ & $\begin{array}{r}\text { living in a } \\
\text { nursing home }\end{array}$ & total & $\begin{array}{r}\text { National Nursing } \\
\text { Home Survey - 2004* }\end{array}$ \\
\hline male & $42 \%$ & $26 \%$ & $42 \%$ & $26 \%$ \\
\hline female & $58 \%$ & $74 \%$ & $58 \%$ & $74 \%$ \\
\hline total & $100 \%$ & $100 \%$ & $100 \%$ & $100 \%$ \\
\hline
\end{tabular}

Source: own calculations based on RAND HRS Data 1996-2008 (Version J); weighted. *Restricted to age 65 and above.

Table 4: Nursing home residence over household composition

\begin{tabular}{|c|c|c|c|c|}
\hline couple & $\begin{array}{r}\text { not } \\
\text { institutionalized } \\
\end{array}$ & $\begin{array}{r}\text { living in a } \\
\text { nursing home }\end{array}$ & total & $\begin{array}{r}\text { National Nursing } \\
\text { Home Survey - 2004* }\end{array}$ \\
\hline no & $43 \%$ & $83 \%$ & $45 \%$ & $80 \%$ \\
\hline yes & $57 \%$ & $17 \%$ & $55 \%$ & $20 \%$ \\
\hline total & $100 \%$ & $100 \%$ & $100 \%$ & $100 \%$ \\
\hline
\end{tabular}

Source: own calculations based on RAND HRS Data 1996-2008 (Version J); weighted. *Over all age groups. 
Table 5: Nursing home residence over race

\begin{tabular}{l|rr|r|r} 
& $\begin{array}{r}\text { not } \\
\text { race }\end{array}$ & $\begin{array}{r}\text { living in a } \\
\text { institutionalized nursing home }\end{array}$ & $\begin{array}{c}\text { National Nursing } \\
\text { total }\end{array}$ & Home Survey - 2004* \\
\hline \hline white & $89 \%$ & $89 \%$ & $89 \%$ & $87 \%$ \\
black & $8 \%$ & $9 \%$ & $8 \%$ & $11 \%$ \\
other** & $3 \%$ & $2 \%$ & $3 \%$ & $2 \%$ \\
\hline total & $100 \%$ & $100 \%$ & $100 \%$ & $100 \%$
\end{tabular}

Source: own calculations based on RAND HRS Data 1996-2008 (Version J); weighted. *Restricted to age 65 and above. **Includes Asian, Native Hawaiian or Other Pacific Islander, American Indian or Alaska Native, and multiple races.

\subsection{Calculation of changes in wealth}

In this study, two-year changes in wealth are calculated by comparing the asset holdings at the beginning and the end of the two-year period. If this difference were divided by disposable income, the saving rate would be calculated according to method one in Appendix A. Whereas in the case of the HRS, saving could be additionally calculated applying the second method of Appendix A, income minus consumption, I focus on saving based on differences in wealth. Besides the advantages and disadvantages of measuring wealth by the asset holdings at the beginning and the end of the two-year period, the sample size would be drastically reduced using the Consumption and Activities Mail Survey (CAMS). CAMS is only available for the years 2001, 2003, 2005, 2007, and 2009. In addition, spending was only assessed for a large random subset of the HRS and the response rate was between 70-80\%. Besides, unit non-response in CAMS increases with age (Hurd and Rohwedder, 2006, p. 11). Whereas wealth was consistently measured from 1996 to 2008, there were major changes in the design of the CAMS (especially between 2003 and 2005). Although the consumption measures of the CAMS are relatively close to the consumption measures in the Consumer Expenditure Survey (CEX) the difference between CAMS and CEX is larger at older ages (Hurd and Rohwedder, 2006, p. 12; Hurd and Rohwedder, 2009, p. 445), which might be an underestimation of spending for older cohorts in the CEX. 


\section{Results}

\subsection{Methodology}

It is a difficult task to measure wealth. Even in cases where wealth is as carefully measured as in the HRS, measurement error is a major concern. Since the saving behavior in old-age is calculated out of wealth holdings in different points in time, the statistical methods to draw conclusions from the data should not be prone to measurement error. The three measures of aggregate wealth changes adapted in this study are as follows (the same three measures are applied by Hurd and Rohwedder (2010)):

1. The first measure is the ratio of mean wealth of the population (or a subgroup) interviewed in two adjacent waves (called "ratio of means"):

$$
\Delta \bar{w}_{t}=\frac{\sum_{h=1}^{n} w_{h, t}}{\sum_{h=1}^{n} w_{h, t-2}}
$$

where $\mathrm{t}=1998,2000, \ldots, 2008$ and $\mathrm{h}$ are the households observed in two adjacent waves.

2. The second measure is the ratio of median wealth of the population (or a subgroup) interviewed in two adjacent waves (called "ratio of medians"):

$$
\Delta w_{t}^{\text {med }}=\frac{w_{t}^{\text {med }}}{w_{t-2}^{\text {med }}}
$$

3. The last measure is the median of households wealth ratios in two adjacent waves (called "median of individual changes"):

$$
\left(\Delta w_{h, t}\right)^{\text {med }}=\left(\frac{w_{h, t}-w_{h, t-2}}{w_{h, t-2}}\right)^{\text {med }}
$$

For the last measure, the household wealth ratios have to be corrected in cases where $\mathrm{w}_{\mathrm{h}, \mathrm{t}-2}$ is negative. The ratio must be multiplied by " -1 " if $\mathrm{w}_{\mathrm{h}, \mathrm{t}-2}$ is negative. After this correction, the households' wealth ratio will correctly reflect wealth increases and decreases over waves.

The two median measures ("ratio of medians" and "median of individual changes") are more robust against outliers. However, the "ratio of means" is the reference measure if one wants to compare saving rates from micro empirical studies to aggregate statistics. The three measures of aggregate wealth changes are calculated over the following two year periods for the HRS: 
1996-1998, 1998-2000, 2000-2002, 2002-2004, 2004-2006, and 2006-2008. Due to the different numbers of observations in each of these two year periods, the ratios are additionally weighted by the number of observations in each time period. All the variables related to wealth changes such as age, current nursing home residence, etc. are taken from the end of the two-year period. ${ }^{21}$

\subsection{Wealth dynamics in the USA}

\subsubsection{Wealth decumulation of nursing home residents in the USA}

Nursing home residents are expected to strongly reduce their wealth holdings. But do they have sufficient wealth holdings to be decumulated? Figure 2 shows mean and median total net wealth of institutionalized households two years prior the current nursing home status. Mean total net wealth increases from $\$ 129,000$ in 1998 to $\$ 158,000$ in 2008 (base year 2000). Median total net wealth decreases $\$ 36,000$ in 1998 , to $\$ 12,000$ in 2006 , and increases again to $\$ 33,000$ in 2008 . Thus, a large fraction of institutionalized household has the ability to dissave.

\section{Figure 2: Total net wealth of institutionalized households over wave}

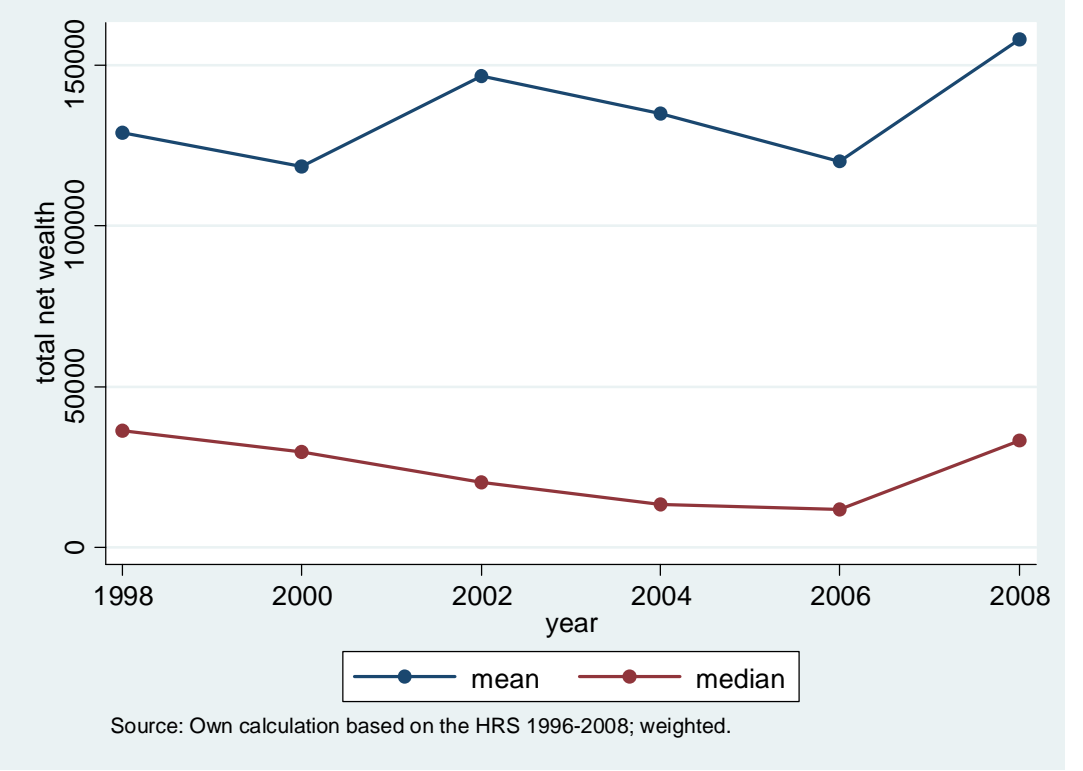

\footnotetext{
${ }^{21}$ Using the end of the two-year period relates the changes in wealth to all nursing home residents, even if the nursing home entry was only a short time before. Using the nursing home status at the beginning of the two-year period, drops important observations since the nursing home resident has to survive the next two years to measure his or her wealth again.
} 
The sample is split according to singles and couples (table 6). ${ }^{22}$ Overall, much more singles are observed to be in a nursing home. Two reasons are responsible: first, older households are more likely to be single households due to the death of the spouse; second, for couples the probability of moving into a nursing home for an individual who needs care is reduced since the partner could provide care as long as he or she is able to. Overall, there are 59 households where both respondent and spouse are institutionalized, which is $14 \%$ of all couples with at least one institutionalized household member. If only one member of a household is in a facility, different resources are needed compared to singles in nursing homes or couples with both members institutionalized.

Table 6: Number of nursing home residents over singles and couples

\begin{tabular}{l|rrr|r} 
& \multicolumn{3}{|c|}{ \# of nursing home residents } & \\
& 0 & 1 & 2 & total \\
\hline \hline single & 23,975 & 2,001 & 0 & 25,976 \\
couple & 21,038 & 350 & 59 & 21,447 \\
\hline total & 45,013 & 2,351 & 59 & 47,423
\end{tabular}

Source: Own calculation based on the HRS 1996-2008.

According to the three measures introduced in section 6.1, two-year wealth changes of the nursing home population are calculated. Appendix E shows the stability of nursing home residents' wealth changes over waves and age classes. At least for singles the measures are relatively stable. Thus, calculating wealth changes over all waves and age classes seems to be a reasonable assumption.

The ratio of means of the two-year percent change in wealth of singles is $-19 \%$, the ratio of medians is even $-91 \%$, and the ratio of individual changes is $-32 \%$. The ratio of means of the two-year percent change in wealth of couples is $-14 \%$, the ratio of medians is $-17 \%$, and the ratio of individual changes is $-9 \%$. To get a better understanding of the wealth changes, wealth paths of a representative nursing home resident are displayed (figure 3 ). Wealth in the year before the individual moved into the nursing home is set to 100 . The two-year ratios are divided by 2 to reflect one-year ratios. In addition, wealth changes are assumed to be constant in absolute terms over the time spent in a nursing home. This corresponds to the assumption that nursing home expenses do not change much in absolute terms over time.

\footnotetext{
${ }^{22}$ The sample size is restricted to the years 1998-2008. This is necessary since the difference in wealth is calculated over a two year period. Since wealth of 1994 cannot be used due to underreporting, the first available year is 1996. Thus, the first time the nursing home status can be used is 1998 .
} 
Figure 3: Simulated wealth paths based on fixed absolute nursing home expenses

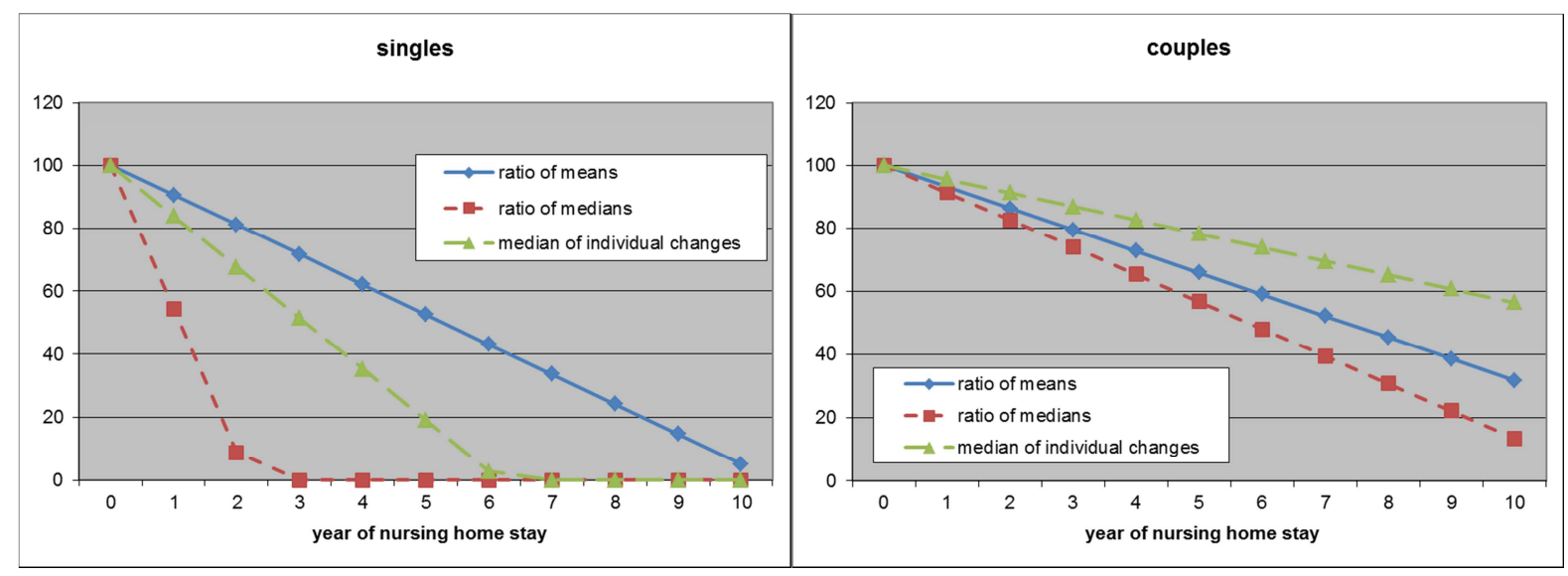

Source: Own calculation based on the HRS 1996-2008; weighted.

For the ratio of medians, the representative single eats up its wealth almost completely in a two-year period. It takes 7 years until wealth is completely decumulated if dissaving is measured via the median of individual changes and 11 years for the ratio of means. For a representative couple, the wealth reduction is not that large. Based on the ratio of medians measure, it takes less than 12 years until wealth is completely consumed. 15 or 23 years are needed for a complete wealth decumulation if the wealth change is measured by the median of individual changes or the ratio of means. The lower wealth decumulation of couples is explained by the fact that couples have higher disposable incomes on average. Thus, if only one member of the household lives in a nursing home, fewer savings must be provided to close the gap.

The strong dissaving in nursing homes fits the official facts about the financing of nursing home expenses on a national level (see section 4.2). 35\% of all the expenses in 2004 are financed by Medicaid. Medicaid supports individuals and families with low resources such as disposable income and wealth. If the median individual runs down his or her wealth after a bit more than two years, Medicaid has to take over.

According to the National Nursing Home Survey in 2004 (Jones et al., 2009, p. 4), the average length of time from admission to the nursing home until the date of the interview was 835 days compared to the median of 463 days. This leads to a complete wealth decumulation for a large fraction of individuals. At least wealth holding will be drastically reduced for most of the nursing home residents at the time of their death. 


\section{How much is covered of average nursing home expenses by household income?}

The rest of this subsection looks at nursing home cost and total household income of HRS respondents and tries to answer the following questions: How large is the fraction of average nursing home expenses that can be financed by households' disposable income? Taking the wealth holdings as given, how long does it take for a nursing home resident until wealth is used up completely? This calculation can be seen as another possibility to calculate wealth decumulation of nursing home residents and should be considered as a robustness test of the results presented above.

The analysis is restricted to the three waves 2004, 2006, and 2008. Only for these years, average nursing home expenses are available from the Genworth Financial Cost of Care Survey. The inflation adjusted U.S. average costs (base year 2000) of a private and semiprivate room are shown in table $7 .^{23}$ In 2006 , the average costs for a private room are $\$ 60,571$ and $\$ 53,413$ for a semi-private room respectively. The other columns present the mean and different quantiles of total household income of HRS respondents. The sample is restricted the same way as before to sustain comparability, which means that only households of respondents above 65 are included. The sample is weighted according to the usual HRS household weights. For singles living alone, the median total household income is $\$ 14,982$, and the mean is $\$ 31,529$ over all three waves. A couple living alone has a median total household income of $\$ 37,032$ and an average total household income of $\$ 56,248$ over the same time period.

\section{Table 7: Nursing home costs and total household income}

\begin{tabular}{|c|c|c|c|c|c|c|c|c|c|c|c|c|}
\hline \multirow[b]{2}{*}{ year } & \multicolumn{2}{|c|}{$\begin{array}{c}\text { nursing home costs } \\
\text { private room semi-private room }\end{array}$} & \multicolumn{10}{|c|}{ total household income } \\
\hline & mean & mean & mean & p25 & $\mathrm{p} 50$ & p75 & p90 & mean & p25 & p50 & p75 & p90 \\
\hline 2,004 & 59,422 & 52,575 & 23,965 & 9,517 & 14,881 & 25,397 & 42,619 & 56,422 & 23,307 & 36,591 & 59,545 & 100,458 \\
\hline 2,006 & 60,571 & 53,413 & 27,822 & 9,584 & 14,929 & 25,855 & 43,744 & 53,626 & 23,575 & 36,511 & 61,141 & 102,482 \\
\hline 2,008 & 61,153 & 54,713 & 42,427 & 9,574 & 15,107 & 26,950 & 47,726 & 58,647 & 24,122 & 38,199 & 64,587 & 112,574 \\
\hline total & 60,380 & 53,569 & 31,529 & 9,553 & 14,982 & 26,086 & 44,384 & 56,248 & 23,722 & 37,032 & 61,435 & 105,795 \\
\hline
\end{tabular}

Source: Genworth Financial Cost of Care Survey 2006, 2007, and 2008. Own calculation based on the HRS 2004-2008; weighted.

Table 8 displays the fraction of nursing home costs that can be financed if total household income is only used to pay nursing home expenses (semi-private room). I refer to the numbers over all three waves. The median income of the category singles is only able to cover $28 \%$ of

\footnotetext{
${ }^{23}$ The median of U.S. nursing home cost is only shown in the Genworth Financial Cost of Care Surveys of 2009 and 2010.
} 
average expenses. For the mean it increases to 59\%. In the case of couples, median income pays for $69 \%$ and mean income for $105 \%$ of nursing home expenses. This is in line with the findings above (figure 3). Wealth decumulation is faster for singles compared to couples as well as for median compared to mean income recipients.

Table 8: Total household income as a fraction of nursing home costs

\begin{tabular}{r|rrrrr|rrrrr} 
& \multicolumn{5}{|c|}{ singles } & \multicolumn{5}{c}{ couples } \\
year & mean & p25 & p50 & p75 & p90 & mean & p25 & p50 & p75 & p90 \\
\hline \hline 2,004 & $46 \%$ & $18 \%$ & $28 \%$ & $48 \%$ & $81 \%$ & $107 \%$ & $44 \%$ & $70 \%$ & $113 \%$ & $191 \%$ \\
2,006 & $52 \%$ & $18 \%$ & $28 \%$ & $48 \%$ & $82 \%$ & $100 \%$ & $44 \%$ & $68 \%$ & $114 \%$ & $192 \%$ \\
2,008 & $78 \%$ & $17 \%$ & $28 \%$ & $49 \%$ & $87 \%$ & $107 \%$ & $44 \%$ & $70 \%$ & $118 \%$ & $206 \%$ \\
\hline total & $59 \%$ & $18 \%$ & $28 \%$ & $49 \%$ & $83 \%$ & $105 \%$ & $44 \%$ & $69 \%$ & $115 \%$ & $197 \%$
\end{tabular}

Source: Genworth Financial Cost of Care Survey 2006, 2007, and 2008. Own calculation based on the HRS 2004-2008; weighted.

To facilitate the subsequent calculation, I assume that the mean income household has mean wealth and the median income household has median wealth. This approximation is appropriate as long as the correlation between retirement income and wealth is sufficiently strong. ${ }^{24}$ Median wealth for singles (couples) is $\$ 88,042$ (\$275,896), and mean wealth is $\$ 265,941(\$ 605,794)$ (table 9).

Table 9: Distribution of total net wealth (excluding secondary residence)

\begin{tabular}{r|rrrrr|rrrrr} 
& \multicolumn{5}{|c|}{ singles } & \multicolumn{4}{c}{ couples } \\
year & mean & p25 & p50 & p75 & p90 & mean & p25 & p50 & p75 & p90 \\
\hline \hline 2,004 & 233,040 & 13,674 & 85,234 & 253,423 & 580,778 & 562,525 & 103,922 & 265,729 & 580,248 & $1,188,717$ \\
2,006 & 282,204 & 10,421 & 90,969 & 281,875 & 629,521 & 649,425 & 111,896 & 284,096 & 627,813 & $1,225,730$ \\
2,008 & 282,969 & 9,598 & 87,978 & 277,772 & 610,490 & 606,733 & 105,414 & 283,930 & 627,845 & $1,231,697$ \\
\hline total & 265,941 & 11,121 & 88,042 & 269,917 & 605,298 & 605,794 & 106,856 & 275,896 & 615,688 & $1,211,507$
\end{tabular}

Source: Own calculation based on the HRS 2004-2008; weighted.

The results (figure 4) are remarkably close to the wealth decumulation measures displayed in figure 3 for singles. In both cases, wealth is completely consumed after a bit more than 2 years for the representative median household (ratio of median). If both calculations are based on the mean, the representative mean single has zero wealth around year eleven of the nursing home stay.

\footnotetext{
${ }^{24}$ Another method is to assign the actual wealth holdings to the median or mean income household. However, this method is not robust against outliers. By chance the wealth holdings of the median income household(s) might be high or low. The higher the number of median income households, the less likely it is to obtain an outlier with regard to wealth. Another possibility is to calculate median wealth holdings of all household between the $49^{\text {th }}$ and $51^{\text {st }}$ income percentile. A similar procedure can be done for the mean. Both yield very similar results compared to the procedure implemented.
} 
Figure 4: Simulated wealth paths based on wealth minus net nursing home expenses
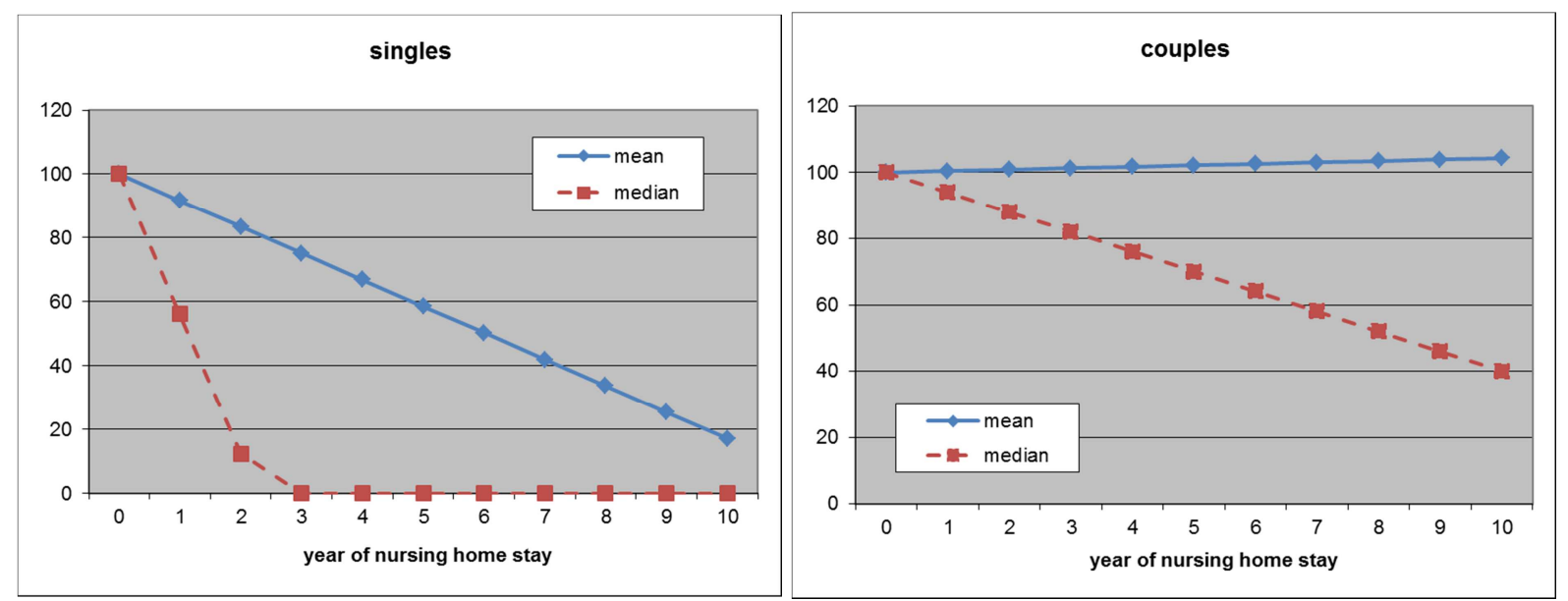

Source: Genworth Financial Cost of Care Survey 2006, 2007, and 2008. Own calculation based on the HRS 2004-2008; weighted.

The calculation based on wealth minus net nursing home expenses shows a slower wealth decumulation for couples compared to figure 3. The main reason for this difference is the fact that only nursing home costs are considered. This might be an adequate assumption for single nursing home residents since almost all the expenses of daily living are part of nursing home costs. However, the spouse living outside the nursing home has to cover additional expenses such as rent, food or a car. This leads to an underestimation of the wealth decumulation for couples using the second method. ${ }^{25}$

To sum up, estimating the effect of wealth decumulation for single nursing home residents is very similar using two different methods. There are larger discrepancies for couples. This difference is mainly driven by expenses of the spouse outside the nursing home, which are not considered in the second calculation method. The results quantify the strong dissaving of the nursing home residents. Leaving them out of the sample might lead to a serious overestimation of the saving rate of elderly households.

\footnotetext{
${ }^{25}$ Other reasons for a discrepancy between the two calculation methods are that passive savings via capital gains or losses and receiving or leaving a inheritance are only included using differences in wealth holdings. In reference to that, heritage from outside the household plays an inferior role for individuals aged 65 and above. Moreover, nursing home costs differ between individuals. Wealthier individuals might choose a more expensive long-term care facility. In addition, long-term care insurance reduces wealth decumulation. Over all respondents of age 65 and above, $11 \%$ report having a long-term care insurance, which covers at least a part of nursing home expenses.
} 


\subsubsection{How strong is the overestimation of the saving rate of the elderly in the USA if institutionalized households are excluded?}

The previous section revealed that nursing home residents strongly dissave. In almost all of the datasets introduced in section 2, institutionalized individuals are not included in the sample. This raises the question, how large the effect on the aggregate saving rate will be if institutionalized individuals are excluded from the sample? To answer this question, mean and median saving rates are calculated for each age.

1. The mean aggregate saving rate is calculated as follows:

$$
\bar{s}_{k}=\frac{\sum\left(\left(\text { wealth }_{t}-\text { wealth }_{t-2}\right) / 2\right)}{\sum \text { income }_{t-1}}
$$

where $\mathrm{k}$ stands for each age from 65 to $95, \mathrm{t}$ for the current period and $\mathrm{t}-2$ for time of the wave before. Saving rates are calculated by using disposable income in the denominator. Since disposable income is only publically available for the years 2000 and 2002, total household income is taken, which includes all kinds of income sources before tax. Above age 75, taxes only play a minor role and the results change only slightly if disposable income is used for the years 2000 and $2002 .^{26}$ Total household income is taken from period t-1 since income is reported for the last calendar year before the interview.

2. The median aggregate saving rate is measured using this formula:

$$
s_{k}^{\text {med }}=\frac{\left(\text { wealt }_{t}^{\text {med }}-\text { wealth }_{t-2}^{\text {med }}\right) / 2}{\text { income }_{t-1}^{\text {med }}}
$$

One problem in calculating saving rates for the oldest old is the strong decrease of the number of observations with age. Although the HRS provides sample sizes of up to 20,000 respondents for each wave (Appendix B), it is necessary to pool all waves from 1996-2008 to obtain a reasonable sample size. Figure 5 shows for each age the sample size and the fraction of institutionalized individuals. The sample size decreases from more than 4,500 observations

\footnotetext{
${ }^{26}$ For a detailed description of the income measure see RAND HRS Data Documentation (Version J, pp. 708710). Rohwedder et al. (2005) provide a calculation of federal, state, and FICA taxes for HRS respondents in 2000 and 2002. Based on their calculations two observations can be made: first, the median sum of federal, state, and FICA taxes is zero from age 74 on. With increasing age taxes become less and less important and the difference between disposable income and total income closes almost completely. Second, the key result presented in figure 7 changes only slightly if median and mean saving rates are computed based on total income as well as disposable income in the denominator for the years 2000 and 2002. The maximum change of the difference between the median saving rates is $0.3 \mathrm{pp}$. The maximum change of the difference between the mean saving rates is $0.4 \mathrm{pp}$ up to age 89 . From age 90 to 95 the absolute change increases from $1 \mathrm{pp}$ to $4 \mathrm{pp}$. However, the larger changes in percentage points for age $90+$ are not more than $13 \%$ relative to the overall difference.
} 
at age 65 to less than 23 observations at age 100. The following analysis is restricted to the age span 65 to 95 years since the number of observations drops from 160 at age 95 to less than 100 at age 96 . The fraction of institutionalized individuals increases from less than $1 \%$ at age 65 to $4.5 \%$ at age 80 growing with almost exponential pace up to $32.2 \%$ at age 95 .

Figure 5: Number of observations and the fraction of institutionalized over age

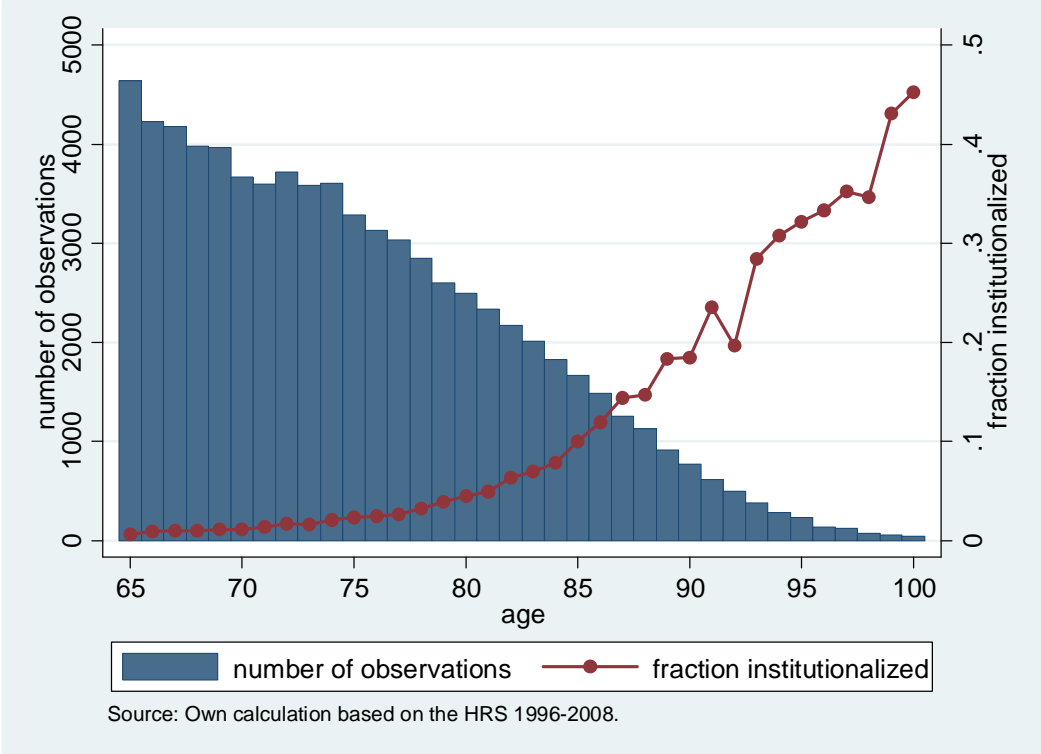

Appendix F shows scatter plots of the obtained saving rates and describes the smoothing of the saving rates over age. The smoothed mean and median saving rates over age and over the two samples (including (corrected saving rate) and excluding (uncorrected saving rate) the institutionalized households) are shown in figure 6.

Figure 6: Corrected and uncorrected mean and median saving rates over age - HRS

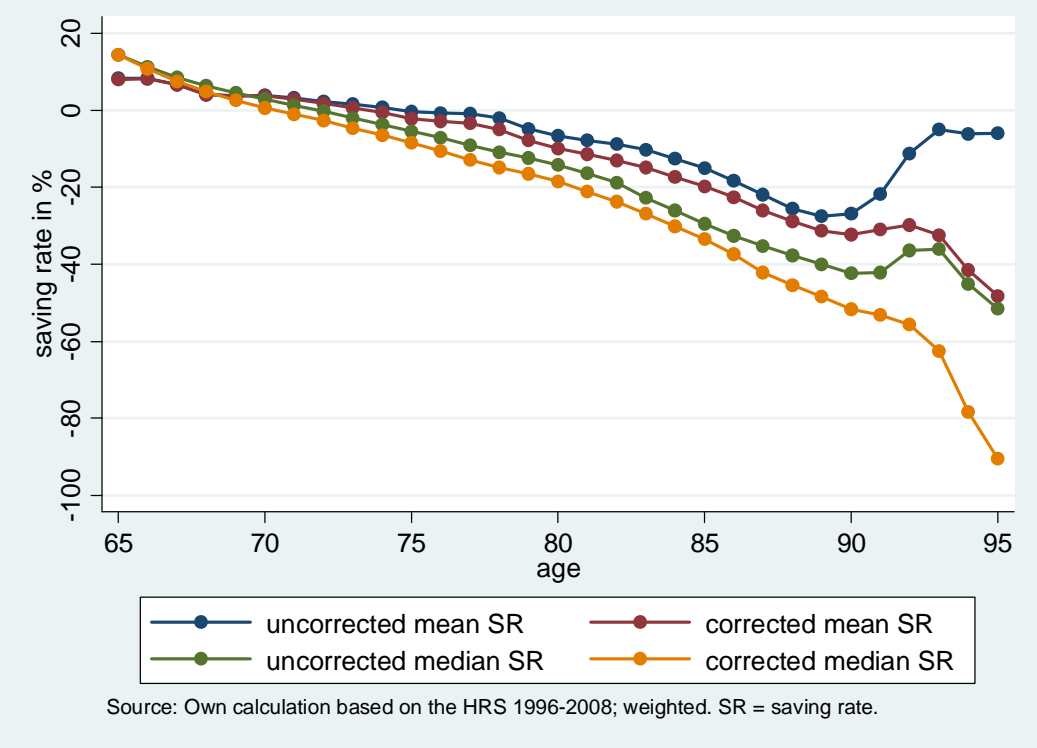


The uncorrected mean saving rate of non-institutionalized households declines from $8 \%$ at age 65 to $-26 \%$ at age 90 , while it increases again from age 90 on. A similar trend can be observed for the uncorrected median saving rate of non-institutionalized households which declines from $14 \%$ at age 65 to $-42 \%$ at age 90 and then increases again from age 91 to $93 .^{27}$ When comparing the saving rates obtained including and excluding institutionalized households, almost no difference can be observed at age 65 . However both corrected mean and median saving rates show a much steeper decline for ages $90+$. The difference in mean and median saving rates is presented in figure 7.

The differences between the corrected and uncorrected saving rates are substantial and increase with age. The difference in mean (median) saving rates at age 80 is $3.3 \mathrm{pp}$ (4.3pp), and increases to $4.7 \mathrm{pp}$ (4.0pp) at age $85,5.4 \mathrm{pp}$ (9.4pp) at age 90, and even more for age 90+. The strong effect for the age group 90+ comes from the strong increase of the fraction of institutionalized from $18.5 \%$ at age 90 , to $32.2 \%$ at age 95 . Excluding the institutionalized from the sample leads to a not explainable increase in saving rates for ages $90+$. If institutionalized households are included, the negative trend of the saving rates over age continues. To sum up, excluding institutionalized households as done before in many studies (table 1) leads to a serious and increasingly overestimation of aggregate saving rates over age.

Figure 7: Difference between the corrected and uncorrected saving rates over age - HRS

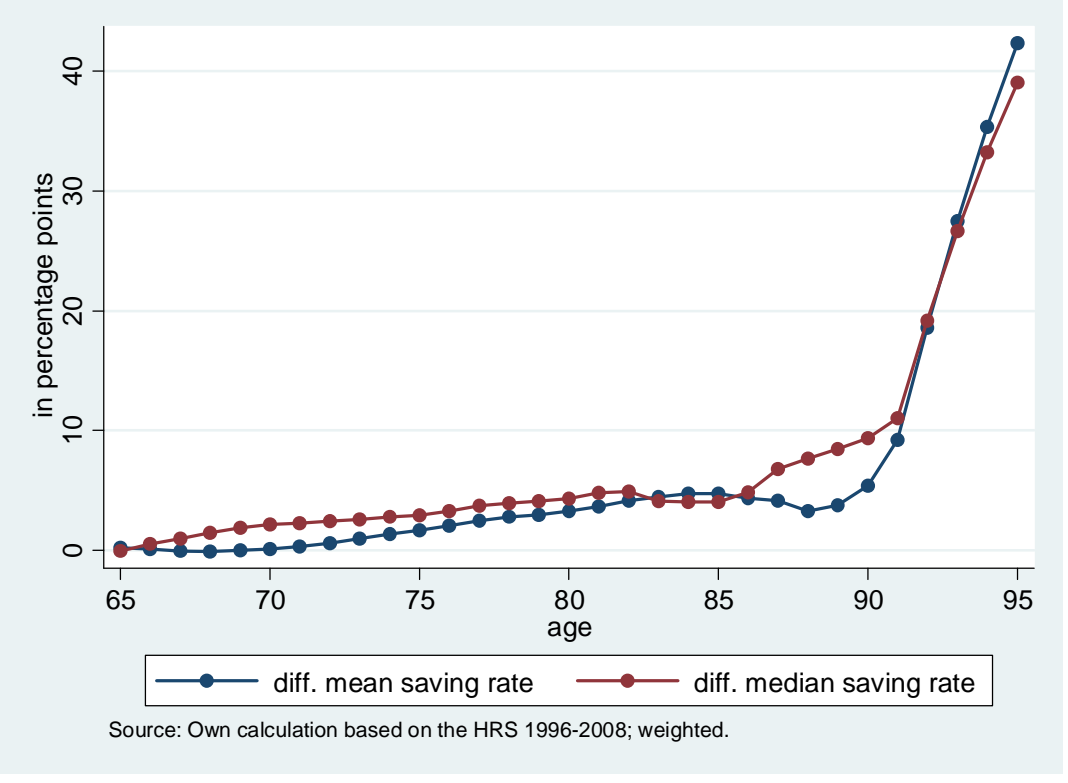

\footnotetext{
${ }^{27}$ Although there are difference in the chosen sample, the results are roughly in line with Hurd and Rohwedder (2006, p. 27).
} 


\section{The German case}

After the investigation of U.S. data, the question arises whether the results carry over to other countries with positive aggregate saving rates in old-age. This section focuses on Germany, one of the countries with the highest aggregate saving rates in old-age among the countries introduced in section 2. One has to be very cautious to carry over the results from the USA since the institutional background differs for these two countries significantly. Since no German dataset is available to investigate directly saving rates in old-age including nursing home residents, this section estimates the corrected saving rates based on different data sources. Section 7.1 presents the institutional backgrounds related to long-term care, how long-term care is financed, and how individual nursing home expenses are calculated over all federal states in Germany. Section 7.2 introduces the German Income and Expenditure Survey (EVS), on which the later investigation is based. Section 7.3 displays the calculation step by step and provides the results. The ongoing aging of the population and the therefore related increase of the institutionalized population might amplify the results in future decades. Section 7.4 quantifies the effects of the demographic development on aggregate saving rates, if institutionalized individuals are not sampled.

\subsection{Long-term care in Germany: population characteristics and institutional background}

\subsubsection{Resident characteristics}

Similar to the USA, also in Germany the fraction of population in nursing homes increases almost exponentially with age. According to the care statistics of the statistical office, in age group 60-65 less than $1 \%$ of individuals live in nursing homes (figure 8). Of age group 80-85 around $7 \%$ live in a nursing home, and the probability of long-term care in a nursing home reaches around $30 \%$ for the oldest age group of 90 and above. Especially for the oldest two age groups, the fraction of institutionalized people increased from 1999 to 2007. 


\section{Figure 8: Institutionalized population over age groups in Germany}

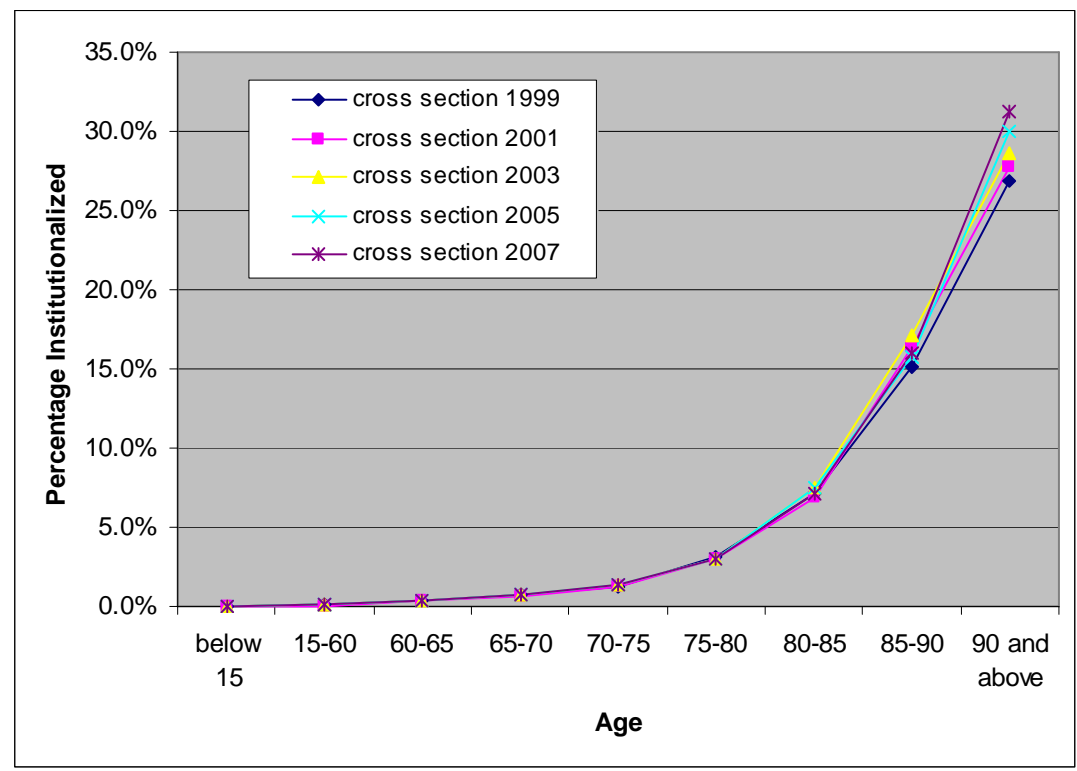

Source: Care statistic (Pflegestatistik) of the statistical office for the years 1999, 2001, 2003, 2005, and 2007. The care statistic includes only individuals who receive payments of the long-term care insurance (care-level I, II, and III). Individuals living in a nursing home of care-level " 0 " are not included. The official numbers are corrected by including individuals of care-level " 0 ", who live in nursing homes. The correction is based on a survey of nursing home residents in 2005 conducted by TNS Infratest Sozialforschung.

The vast majority of the nursing home population is made up of women: in 2003, for example, $78 \%$ of the nursing home inhabitants consist of females and $22 \%$ of males (Pflegestatistik 2003: Pflege im Rahmen der Pflegeversicherung - Deutschlandergebnisse, table 1.1). Only a minority of the institutionalized population actually has a partner: in 2003, $8.7 \%$ of the inhabitants are married or live in a partnership, while $65.7 \%$ are widowed, $6.6 \%$ divorced, and $18.9 \%$ single (Mikrozensus, 2003). Roughly speaking, the resident characteristics are similar to the USA. The main difference is the higher fraction of women in German nursing homes. Table 10 shows gender and marital status of nursing home residents in 1999 and 2003.

\section{Table 10: Gender and marital status of nursing home residents in 1999 and 2003}

\begin{tabular}{|c|c|c|c|c|}
\hline \multicolumn{4}{|c|}{ Mikrozensus 1999} & \\
\hline gender & single & married| & total & \\
\hline$\overline{\text { male }}$ & $81.2 \%$ & |18.8\% & $100.0 \%$ & \\
\hline female & $95.4 \%$ & $4.6 \%$ & $100.0 \%$ & \\
\hline total & $92.4 \%$ & $7.6 \%$ & $200.0 \%$ & \\
\hline & single & married & total & total $^{*}$ \\
\hline male & $17.0 \%$ & $3.9 \%$ & 20.9\% & $21.1 \%$ \\
\hline female & $75.5 \%$ & $3.6 \%$ & $79.1 \%$ & $78.9 \%$ \\
\hline total & $92.4 \%$ & $7.6 \%$ & $100.0 \%$ & $100.0 \%$ \\
\hline
\end{tabular}

\begin{tabular}{|c|c|c|c|c|}
\hline \multicolumn{5}{|c|}{ Mikrozensus 2003} \\
\hline & single & married| & total & \\
\hline male & $77.9 \%$ & $22.1 \%$ & $100.0 \%$ & \\
\hline female & $94.9 \%$ & $5.1 \%$ & $100.0 \%$ & \\
\hline total & $91.3 \%$ & $8.7 \%$ & $100.0 \%$ & \\
\hline & single & married & total & total $^{\star \star}$ \\
\hline male & $16.4 \%$ & $4.7 \%$ & $21.1 \%$ & $22.0 \%$ \\
\hline female & $74.9 \%$ & $4.0 \%$ & $78.9 \%$ & $78.0 \%$ \\
\hline total & $91.3 \%$ & $8.7 \%$ & $100.0 \%$ & $100.0 \%$ \\
\hline
\end{tabular}

Source: Mikrozensus 1999 and 2003; *Pflegestatistik 1999; **Pflegestatistik 2003. 


\subsubsection{How is long-term care financed?}

All individuals in nursing homes have to pay their own expenses if they can afford it. The expenses are partly covered if the recipient is classified under one of three levels of care granted under long-term care insurance. The benefit is $€ 1,023$ per annum for care level one, $€$ 1,279 for care level two, and $€ 1,432$ for care level three. ${ }^{28}$ Around $90 \%$ of the German population are covered under the social long-term care insurance, which is currently financed (2010) via a contribution rate of $1.95 \%$ of gross income for individuals with children and $2.2 \%$ without children up to a certain income threshold. Mainly higher income earners and civil servants, who are not part of the social insurance system, are obliged to purchase equivalent private long-term care insurance. Health expenditures are covered by the social health care insurance for the same $90 \%$. Buying an additional long-term care insurance to pay part of the costs not covered by the public long-term care insurance is possible, but plays a minor role in the current financing of nursing home expenses. ${ }^{29}$ If a nursing home inhabitant is not able to cover the net expenses (after the payment of private or social long-term care insurance is subtracted) out of his or her disposable income or wealth, children have to step in. They are obliged ${ }^{30}$ to pay the costs not covered from their current income or wealth after an amount retained for their own necessities is subtracted. Social assistance, which is funded by general taxation, contributes to the funding of long-term care if none of the above mentioned sources are available. The main difference in financing long-term care between the USA and Germany is the relatively generous benefit of the long-term care insurance, which is not means-tested and reduces the individuals' nursing home expenses significantly.

\subsubsection{Costs of long-term care in nursing homes}

Nursing home expenses are split into three parts: payment for care depending on the care level needed, costs for board and lodgings, and investments. The statistical office published the daily rates for care as well as board and lodgings costs in their care statistic for the years 1999, 2001, 2003, 2005, and 2007. Investment expenses rely on the PAULA data base of the BKK-Bundesverband. Table 11 reports the average nursing home expenses per resident over all federal states, gross as well as net of the benefit paid by the long-term care insurance.

\footnotetext{
${ }^{28}$ Since the introduction of benefits for nursing home residents from the long-term care insurance in July 1996 , the benefits remained unchanged until June 2008. This time-span covers the complete period of investigation.

${ }^{29}$ Only $1 \%$ of the population have a voluntary private complementary long-term care insurance (OECD, 2005).

${ }^{30} \S 1601$ BGB.
} 
Appendix $G$ describes in detail how the expenses are calculated. Since the later analysis focuses on the years 1998 and 2003, only the results for 1999 and 2003 are reported.

Table 11: Average gross and net nursing home expenses per resident over all federal states

\begin{tabular}{l|rr|rr} 
& \multicolumn{2}{|c|}{$\mathbf{1 9 9 9}$} & \multicolumn{2}{c}{$\mathbf{2 0 0 3}$} \\
federal state & overall gross costs & overall net costs & overall gross costs & overall net costs \\
\hline \hline Baden-Württemberg & 2,470 & 1,338 & 2,662 & 1,535 \\
Bavaria & 2,337 & 1,189 & 2,585 & 1,446 \\
Berlin & 2,417 & 1,271 & 2,624 & 1,477 \\
Brandenburg & 1,923 & 771 & 2,129 & 934 \\
Bremen & 2,536 & 1,384 & 2,733 & 1,576 \\
Hamburg & 2,649 & 1,521 & 2,766 & 1,640 \\
Hesse & 2,648 & 1,491 & 2,610 & 1,469 \\
Meckl. Western Pomerania & 1,822 & 656 & 1,938 & 760 \\
Lower Saxony & 2,372 & 1,221 & 2,484 & 1,348 \\
Northrhine-Westphalia & 2,626 & 1,476 & 2,693 & 1,561 \\
Rhineland Palatinate & 2,452 & 1,311 & 2,445 & 1,322 \\
Saarland & 2,430 & 1,303 & 2,452 & 1,336 \\
Saxony & 1,872 & 778 & 1,973 & 814 \\
Saxony-Anhalt & 1,903 & 751 & 2,159 & 973 \\
Schleswig-Holstein & 2,256 & 1,127 & 2,648 & 1,519 \\
Thuringia & 1,749 & 701 & 1,988 & 831 \\
\hline Germany & 2,365 & 1,214 & 2,526 & 1,392
\end{tabular}

Source: Care statistic (Pflegestatistik) of the statistical office for the years 1999 and 2003. Additional sources are the PAULA data base of the BKK-Bundesverband and Schneekloth (2006) as described in Appendix G.

The average gross nursing home expenses are $€ 2,365$ in 1999 and $€ 2,526$ in 2003, while net expenses are much lower, adding to $€ 1,214$ in 1999 and $€ 1,392$ in 2003 . The entity of the costs differs a lot between federal states, ranging from $€ 656$ in Mecklenburg-Western Pomerania to $€ 1,521$ in Hamburg in 1999 . Thus, it is important to take the variation between federal states into account.

\subsection{The German Income and Expenditure Survey (EVS)}

Of all available datasets, the German Income and Expenditure Survey (EVS) is the most suitable to calculate saving rates in old-age. Appendix $\mathrm{H}$ argues why other German datasets, where calculations of saving rates are possible, are less appropriate. The EVS is supposed to be representative for the German population, although the institutionalized population is not sampled and in addition, the Federal Statistical Office excludes households above an upper income threshold. ${ }^{31}$ The latter restriction, however, can be expected to have a small effect on

\footnotetext{
${ }^{31}$ The threshold of net monthly income is $€ 17,895$ in 1998 and $€ 18,000$ in 2003.
} 
the estimation of saving profiles among retired households (Sommer, 2005, 2008). The EVS started in 1962 and since 1973 is conducted every five years. The analysis is restricted to the years 1998 and 2003, since the introduction of the German social long-term care insurance in $1995 / 1996$ changed the way long-term care is financed. This rules out the survey years from 1993 backwards.

In the EVS, savings can be measured in two ways: as the sum of savings flows to and from certain asset categories and as the difference between income and consumption. Since the EVS is no panel dataset, changes in the level of wealth can only be calculated using a synthetic panel. I rely on savings calculated as the sum of savings flows since this measure is closest to the aggregate statistic of the German Bundesbank. ${ }^{32}$ In contrast to the analysis of HRS data, this measure captures only active savings. All 42,744 (49,720) households available in 2003 (1998) are included in the analysis. The results are weighted using the official EVS weights for Germany.

\subsection{Do nursing home residents matter? The calculation of corrected saving rates}

A three-steps procedure is used to calculate the corrected average saving rates: first, different measures of saving rates over the life-cycle are calculated based on the EVS 1998 and 2003; second, it is quantified how much of average nursing home expenses is covered by current income; third, corrected mean aggregate saving rates are calculated based on the fraction of the population in nursing homes for each year of age.

To get an impression of saving rates in the EVS in 1998 and 2003, aggregate saving rates are calculated for each of the measures introduced in subsection 6.1 and all ages separately. Appendix I shows scatter plots of the obtained saving rates and describes the smoothing of the saving rates over age. The smoothed saving rates over age for each of the three measures are plotted in figure 9.

\footnotetext{
${ }^{32}$ According to the German Bundesbank, the aggregate saving rate of private households was $10.1 \%$ in 1998 and $10.3 \%$ in 2003 compared to $11.1 \%$ in 1998 and $12.0 \%$ in 2003 based on EVS data.
} 
Figure 9: Smoothed saving rates over age
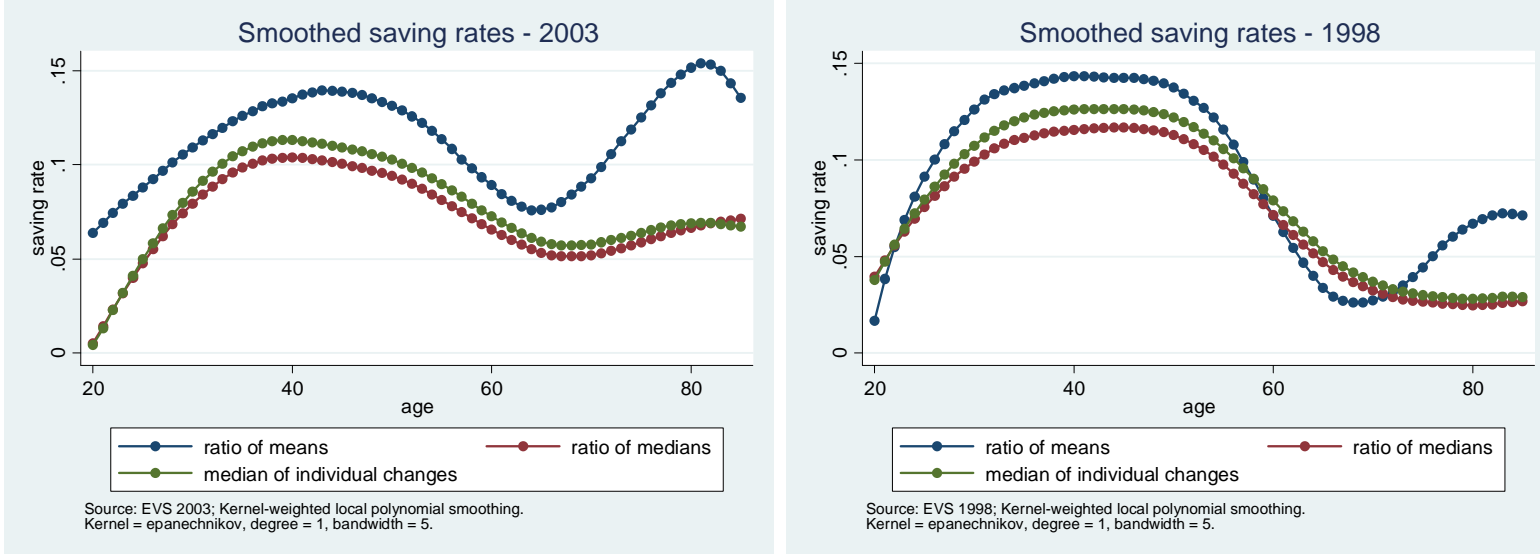

Both cross sectional saving patterns of 1998 and 2003 have a hump-shape profile over the life-cycle. However, the saving rates do not become negative in old-age. The ratio of medians or the median of individual changes, which show very similar profiles over the life-cycle, do not decrease further from a certain point in retirement on. The ratio of median saving rates even increases again during retirement. These results are in line with Börsch-Supan et al. (2003), which use the EVS from 1978-1993.

The next step is to estimate mean saving, mean income and mean saving rates for the institutionalized population. The nursing home population is expected to be selective sample of the whole populations: in the USA, for example the risk of institutionalization is higher among low income households (Börsch-Supan, 1989). To partly capture this effect, the sample is split according to household composition. ${ }^{33}$ As seen in section $7.1 .1,78 \%$ of the nursing home population in 2003 is made up of females and 22\% of males (care statistics 2003). In addition, 8.7\% of the residents are married (Mikrozensus, 2003). Based on these fractions, the sample is split into three parts: single females, single males, and married individuals. The same is done for $1998 .^{34}$ Net household income is equivalised dividing household income by the square root of household size. Subsequently, the individual cost of a nursing home stay is subtracted according to the federal state the individual lives in (see Appendix G). ${ }^{35}$ Moreover, additional expenses not covered by the nursing home are

\footnotetext{
${ }^{33}$ Single females have lower income compared to single males or couples. If the constructed nursing home population consists of a high fraction of females, this translates automatically in a lower average income of the nursing home population.

${ }^{34}$ For 1998 there exists no care statistic. The closest care statistic is from 1999. The marital status of an individual is not surveyed in the care statistic, therefore the exclusive reports about individuals in need of care of the federal statistical office is used. The bold numbers in table 10 show the fractions of the three groups in 1999 and 2003.

${ }^{35}$ The nursing home expenses of 1999 are inflation adjusted to obtain the expenses at the level of 1998. The inflation adjustment is based on the average price development of nursing home prices (cost of care + board and lodging) between 1999 and 2007 of $1.27 \%$.
} 
subtracted (e.g. additional payments for medication, clothes, cigarettes, alcohol, newspaper, ...). The calculation is based on the EVS and separately done for each age. E.g. for all ages above 85 , the average additional expenses are $€ 207$ per month in 2003 and $€ 138$ per month in 1998 based on conservative estimates. ${ }^{36}$ If there is income left after the subtraction of expenses, it is assumed that all the money is saved. If nursing home expenses exceed net income, wealth has to be decumulated.

It is central for the results that the nursing home residents have enough wealth to dissave. Appendix $\mathbf{J}$ shows mean and median total net wealth over the three socio-demographic groups and age 65 to 85 , restricted to those households for whom expenses exceed their current income. It turns out that even single females with the lowest incomes and who are decumulating their wealth still have a median net wealth of at least $€ 10,000$ and a mean net wealth of at least $€ 50,000$.

For each year of birth, mean income and the newly constructed mean saving are calculated for all three socio-demographic groups (single female and males, married individuals) separately. As there is some variation in the data on a yearly basis, the same technique applied before to the saving rates is used to smooth the observations over the life-cycle. The oldest observed individual in the EVS is 85 years old, so that no values are observed from age 86 on. The smoothed value of age 85 is plugged in for every year until age 95 since just for these ages nursing home residents become more and more relevant. Afterwards mean income and mean saving are combined for each year of age, weighting each of the three groups according to the relative size of the nursing home population. This procedure ensures that more low income households are represented in the constructed nursing home population since the mean income of single females is below the mean income of single males, as well as that of married individuals. Figure 10 displays the combined mean income and saving for the constructed nursing home population from age 60 to 85 .

\footnotetext{
${ }^{36}$ Since to the knowledge of the author there is no source of information what a nursing home resident consumes in addition to the expenses for the nursing home, the following procedure was chosen to estimate the additional expenses. The estimates are based on the detailed consumption diary of the non-institutionalized population in the EVS. For each year of age all consumption categories are added, which are not covered by the nursing home and still needed by a nursing home resident. This includes clothes, health care expenses financed by own means, haircuts, items of body care, telephone, radio, TV, radio (and television) license fee and related repairs, alcohol (only available in 2003), and tobacco (only available in 2003). The quarterly amount is transformed into a monthly amount and adjusted by household size (square root). The mean consumption values are smoothed over age using a kernel-weighted local polynomial smoothing. To obtain a conservative estimate the lower bound of the $95 \%$ interval is taken. Since we have only observations up to age 85 , the value for age 85 is carried forward up to age $95+$.
} 
Figure 10: Combined mean income and saving for the constructed nursing home population
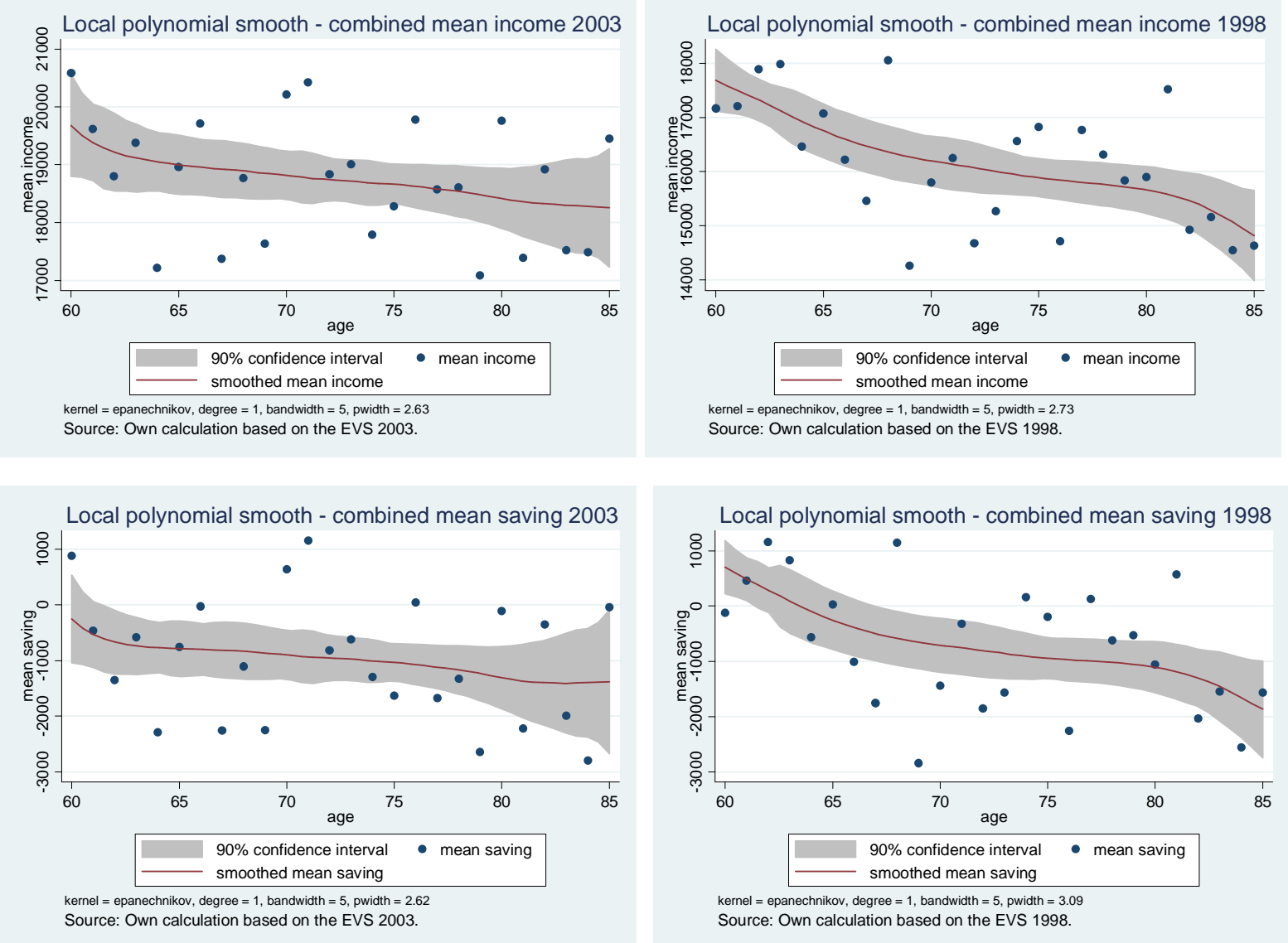

The construction of the mean income and saving for the institutionalized population incorporates the known information about the institutionalized population (age, federal state, care level, gender, and marital status). However, since all the other characteristics are unobserved, the implicit assumption made is that the institutionalized population corresponds to the non-institutionalized population with respect to the unobserved characteristics.

The low or even negative mean saving of the constructed nursing home population is in line with previous findings. Spieß and Wagner (1993) clarify this point using data from the German Socio-Economic Panel Study (SOEP) in $1992 .{ }^{37}$ They conclude that more than 50\% of singles aged 60 years and older in West Germany and 80\% in East Germany are not able to cover nursing home expenses after disposable income and the contributions of the long-term care insurance are taken into account. For married individuals the percentage is lower (15\% in West Germany and $49 \%$ in East Germany). This is supported when looking at the nursing

\footnotetext{
37 The social long-term care insurance came into effect on the 1. January, 1995. They include the planed payments of social long-term care insurance in their analysis.
} 
home inhabitants who are able to finance the expenses fully on their own. Krug and Reh (1992) find that only $33 \%$ were able to finance their nursing home by their own means in 1988. ${ }^{38}$ New data from 2005 delivers additional evidence (Schneekloth, 2006). Considering the payments of the social long-term care insurance, $36 \%$ of the nursing home population in need of long-term care drew on social assistance in 2005 and were not able to pay fully for all expenses.

Finally, the corrected aggregated mean saving rates including the nursing home population can be constructed. ${ }^{39}$ For each age $t$, the corrected aggregated saving rate is calculated as follows:

saving_rate $_{t}=\frac{\text { mean_saving }(\text { resident }=0)_{t} \cdot\left(1-\operatorname{prob}(\text { resident }=1)_{t}\right)+\text { mean_saving }(\text { resident }=1)_{t} \text { prob }(\text { resident }=1)_{t}}{\text { mean_income }(\text { resident }=0)_{t} \cdot\left(1-\text { prob }(\text { resident }=1)_{t}\right)+\text { mean_income }(\text { resident }=1)_{t} \text { prob }(\text { resident }=1)_{t}}$

where resident $=0$ indicates the non-institutionalized population and resident $=1$ indicates the constructed institutionalized population. The construction of the weights (fraction of households with at least one institutionalized member: prob(resident $=1)_{t}$ ) consists of two steps: first, the care statistics provide the fraction of institutionalized individuals in brackets including 5 years of age. To obtain the fraction of institutionalized individuals for each age separately a controlled remote data processing was performed; ${ }^{40}$ second, the care statistic is on an individual basis and not on a household basis. Since income and savings are measured on a household level, the ratios of institutionalization are as well transformed to a household level. The corrected and uncorrected aggregated mean saving rate are displayed in figure 11. This is done for each age from age 20 to 94 . The highest age category summarizes all ages from age 95 on since the population size is only available for age class $95+$.

\footnotetext{
${ }^{38}$ The fraction seems to be relatively low. This could be due to the fact, that the social long-term care insurance was implemented not until 1995/1996.

39 The analysis is restricted to the construction of the corrected aggregated mean saving rates. The chosen procedure is not able to calculate the corrected aggregated median saving rates. The procedure constructs the institutionalized population out of the observed population by taking mean income and saving over three different groups. Taking the median income and saving is possible, but this biases the construction of the corrected median saving rate since the constructed institutionalized population has only one value for income and saving, namely the combined median value over the three groups.

${ }^{40}$ Forschungsdatenzentrums der Statistischen Ämter des Bundes und der Länder, care statistic, 1999 and 2003 , own calculations.
} 
Figure 11: Corrected and uncorrected mean saving rate - EVS
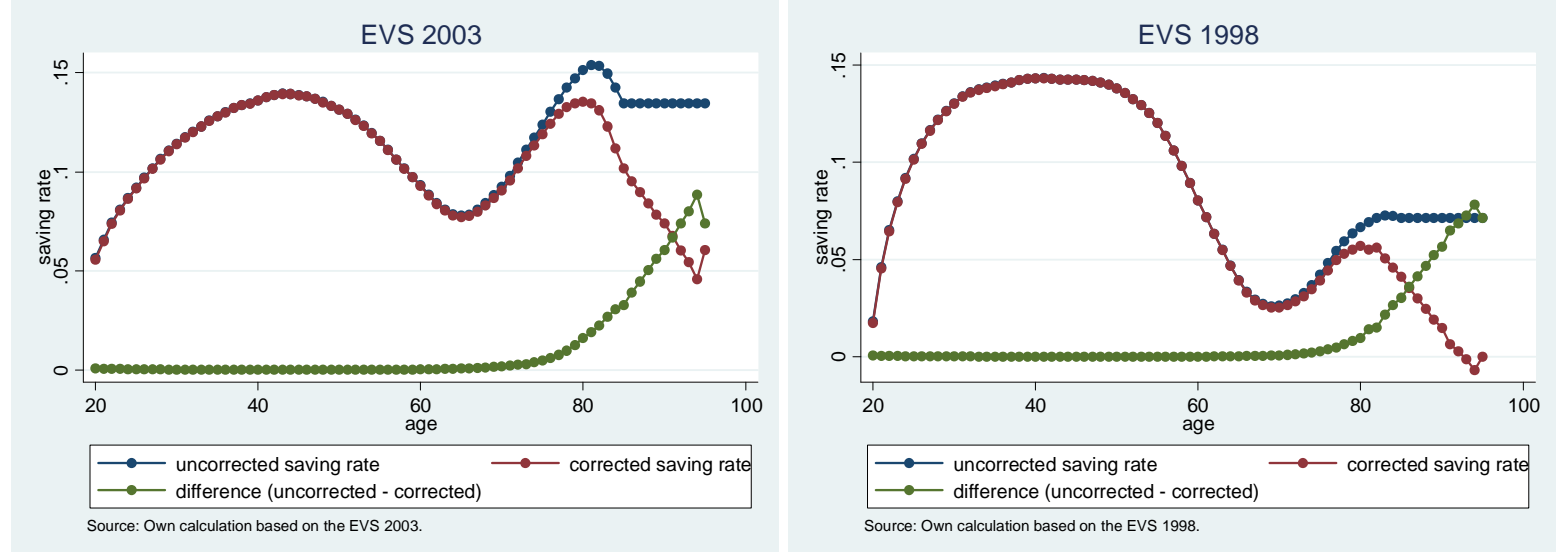

As can be seen, the difference in the corrected and uncorrected aggregated mean saving rate becomes apparent from age 75 on. The difference increases from 1.6pp (1.0pp) at age 80, to 3.3pp (3.0pp) at age 85, to 6.0pp (5.7pp) at age 90, up to $7.4 \mathrm{pp}$ (7.1pp) for age $95+$ in 2003 (1998). The increase of the corrected saving rate from age 94 to age $95+$ comes from the fact that the fraction of institutionalized is higher among individuals aged 94 compared to individuals aged $95+$.

Overall, the difference in the mean saving rate is comparable to the USA. And this despite the reduction of net expenses due to the social long-term care insurance in Germany. The social long-term care insurance came into effect in 1995/ 1996. One of the main reasons for the introduction of the social long-term care insurance was the concern about the financial burden of nursing home residents and their families. Since a large fraction of the nursing home residents had to rely at least partly on social assistance (Krug and Reh, 1992), the financial costs for social assistance increased, which had to be paid by the municipalities. The following calculations quantify the effect of the social long-term insurance on saving rates. Mean saving rates over age are calculated without any support of the long-term care insurance. The results are displayed in figure 12.

It can be seen that corrected saving rates turn highly negative in old-age. The corrected saving rates without long-term care benefits are $2.5 \mathrm{pp}$ (2.7pp) lower at age 75 compared to the uncorrected saving rates without long-term care benefits. The difference increases to 28pp (32pp) at age 90 . 
Figure 12: Corrected and uncorrected mean saving rate without long-term care insurance - EVS
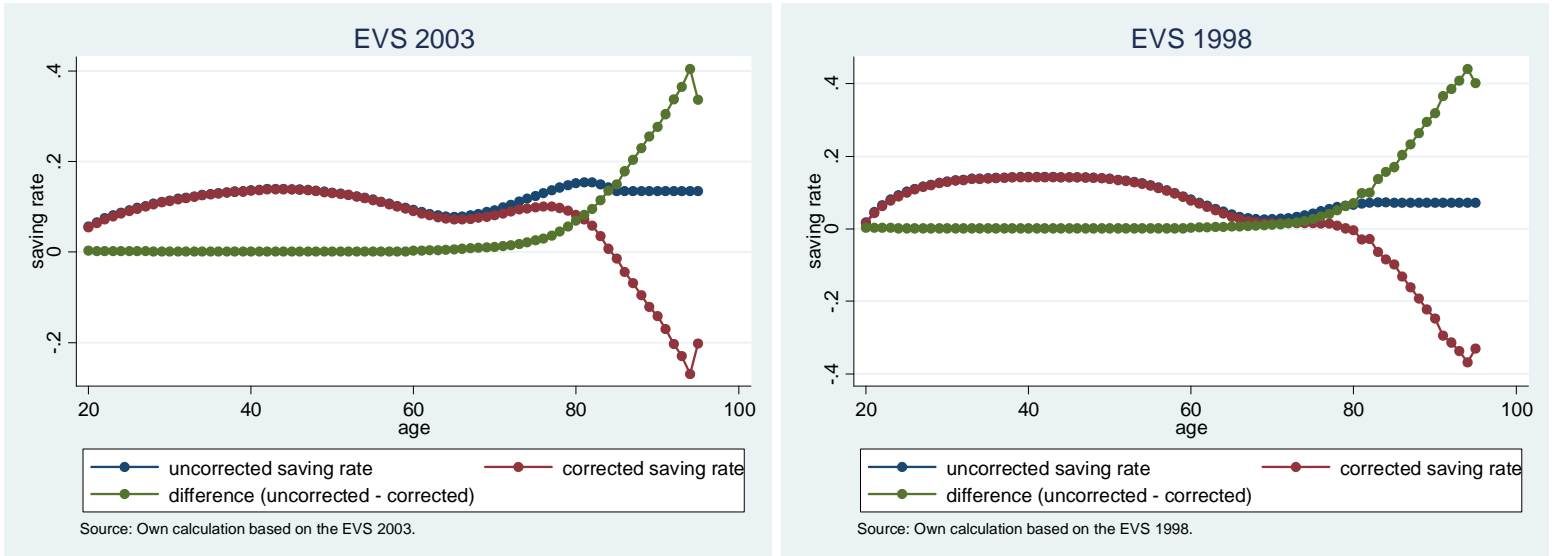

To sum up, including institutionalized individuals makes a difference in calculating aggregate saving rates for Germany. The differences in aggregate mean saving rates make up $7 \mathrm{pp}$ for the oldest age group 95+. The difference is reduced through the benefits of the social long-term care insurance. Without the social long-term care insurance saving rates in old-age would even become negative in old-age. The long-term care expenditure risk is lowered significantly by the German long-term care insurance.

\subsection{Influence of an aging society on aggregate saving rates}

Using Germany as an example, this subsection quantifies the effect of the ongoing aging of the industrialized populations with respect to the nursing home population on saving rates. If one assumes that the fraction of institutionalized individuals for every year of age stays constant, ${ }^{41}$ the difference in the saving rates in old-age should remain the same holding all the other factors constant.

The main influence of population aging is on the aggregate saving rate including all ages. This is due to the fact that older age groups increase their relative weight, e.g. according to the 12th coordinated population forecasting of the federal statistical office the fraction of age

\footnotetext{
${ }^{41}$ There are two effects working in opposite directions: First, medical progress could increase the number of healthy years, delaying the entry into a nursing home to older ages (Rothgang, 2001). Second, more single households, less children per parent, and higher disability rates among younger cohorts could reduce the age at which individuals enter a nursing home (Lakdawalla et al., 2003; Schnabel, 2007, p. 15). Schnabel (2007) forecasts the frequency of long-term care rates for Germany on constant prevalence rates. Augurzky et al. (2007, p. 58) use constant fractions of individuals in nursing home per age group as their reference category to calculate the demand for long-term care in nursing homes. Comparing the care statistic of 1999 and 2007, up to age 85 the fraction of institutionalized individuals remains almost constant. Above 85, there is an increase in the fraction of institutionalized from 1999 to 2007.
} 
group 80-84 increases from $1.6 \%$ in 1999 to $6.4 \%$ in 2050 and the fraction of age group 90-94 increases from $0.5 \%$ in 1999 to $2.5 \%$ in 2050 (figure 13).

Figure 13: Estimated fraction of the oldest old on the total population over time

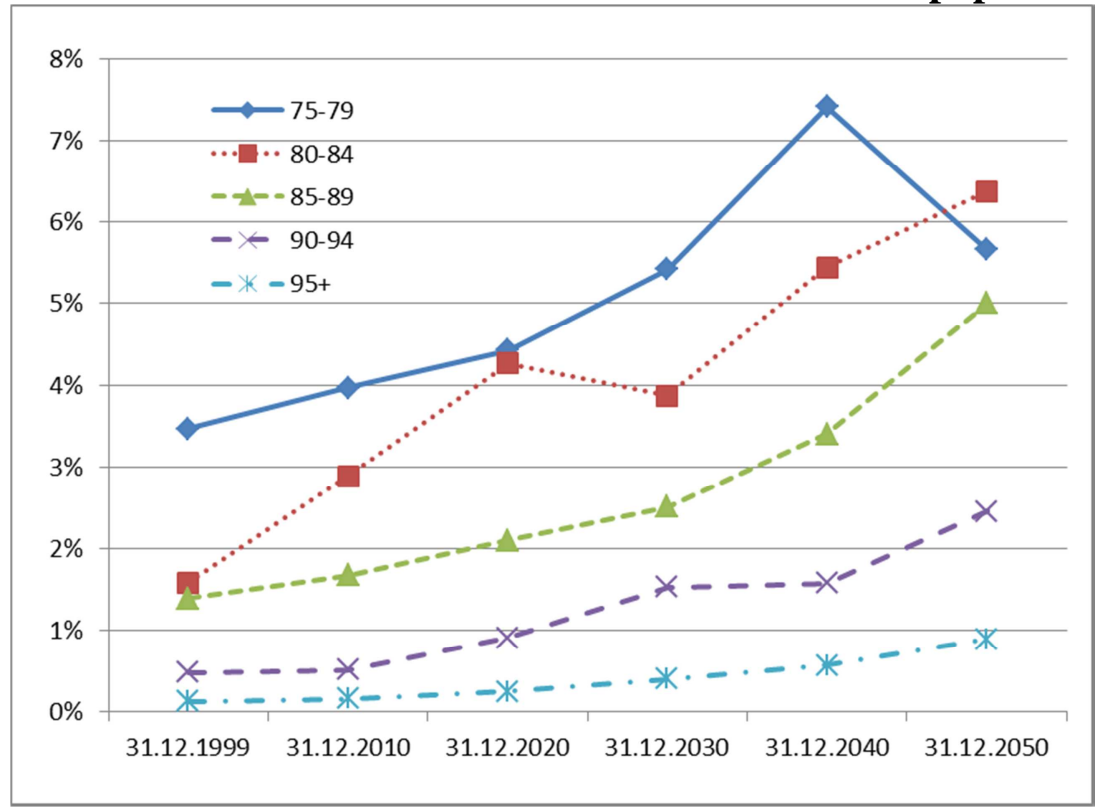

Source: Own calculations based on the results of the 12th coordinated population forecasting (31.12.2008). Assumptions according to the lower bound of the middle scenario (scenario 1-W1).

\section{Figure 14: Fraction of the institutionalized population on the total population}

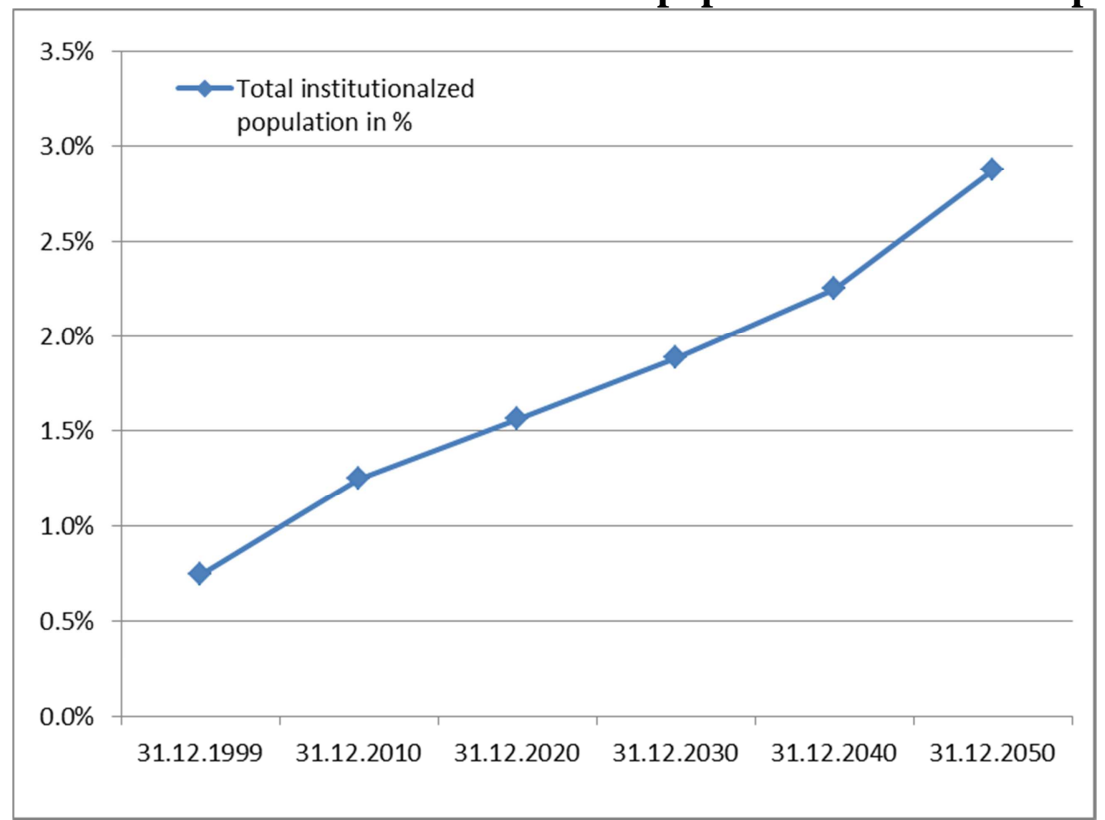

Source: Own calculations based on the results of the 12th coordinated population forecasting (31.12.2008) and the care statistics of 1999 and 2007.

Overall the number of nursing home residents will increase from $0.7 \%$ in 1999 to $2.9 \%$ in 2050 (figure 14). This corresponds to 1,995,000 nursing home residents in 2050 (the forecasts 
are close to the calculation of Enste and Pimpertz (2008) based on the 11th coordinated population forecasting and the care statistic of 2005).

To quantify the effect of an increasing nursing home population on the aggregate saving rate, the aggregate saving rate is calculated as follows:

$$
\text { saving_rate } \text { aggregate } ; k_{t=20}=\sum_{t=95+}^{T}\left(\frac{\text { population }_{t ; k}}{\sum_{t=20}^{T=95+} \text { population }_{t ; k}}\right) \cdot \text { saving _rate }_{t}
$$

where the aggregated saving rate is the weighted sum of the saving rates for each age. The initial age is set to 20 since the household head must be at least 20 years old in the EVS. The summation ends at the age category $95+$. The weights for each age correspond to the relative population size at each age $t$. The saving rates for each age $t$ are assumed to be the same compared to the results obtained from the EVS in 1998 or 2003. Only the weights for each age change over time according to the $12^{\text {th }}$ coordinated population forecasting. Aggregate saving rates are calculated based on the population forecast of $k=2010,2020,2030,2040$, and 2050. Finally, the difference between the corrected and uncorrected aggregated saving rate is taken and displayed in figure 15.

Figure 15: Difference between the corrected and uncorrected aggregated saving rate

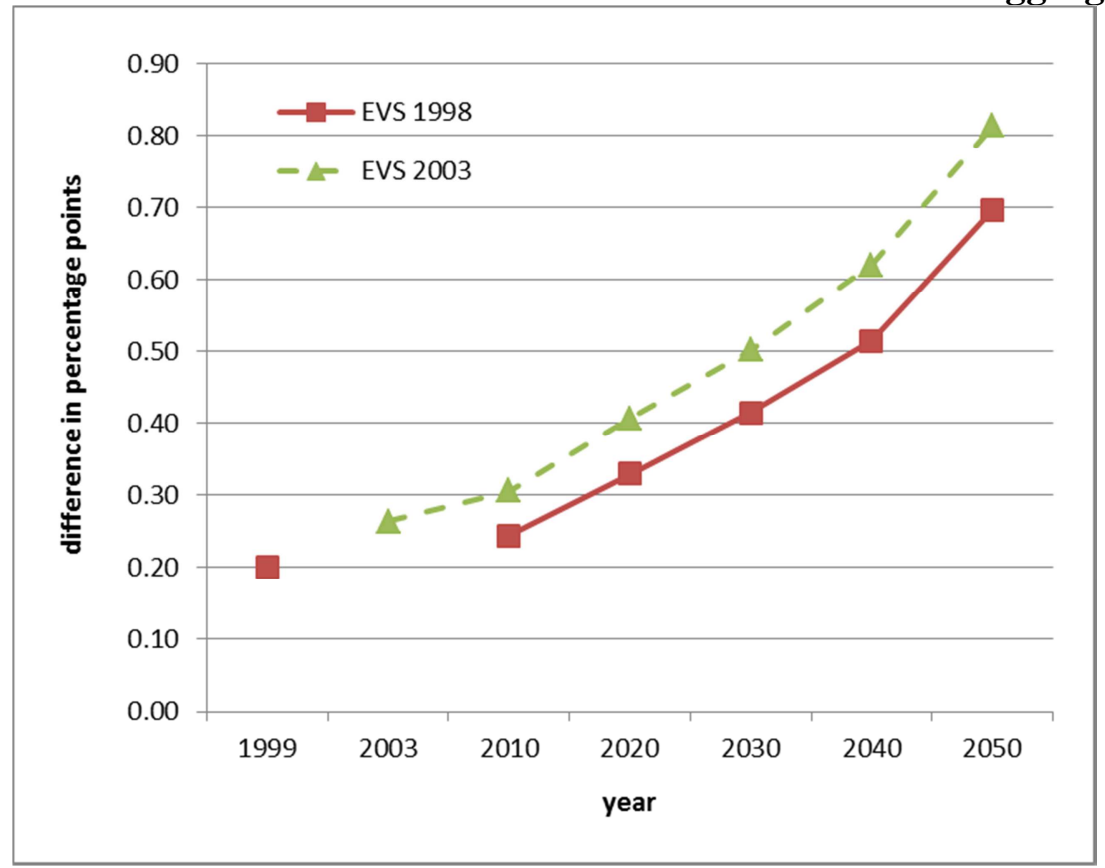

Source: Own calculations based on the results of the 12th coordinated population forecasting (31.12.2008), the care statistics of 1999 and 2003, and the EVS 1998 and 2003. 
Overall, the difference increases over time, which reflects the higher fraction of elderly, who move at a constant rate into a nursing home. The difference between the aggregated saving rates is only 0.20 percentage points in 1999 and $0.26 \mathrm{pp}$ in 2003. The difference increases to 0.70pp based on the EVS 1998 and 0.81pp based on the EVS 2003 in the year 2050. Thus, the consequences of the nursing home population on aggregate saving rates seem to be limited. However, one has to keep in mind that the results are based on old-age incomes, benefits of the long-term care insurance, and nursing home expenses as in 1998/ 2003. If future old-age income declines in real terms, benefits of the long-term care insurance are less generous ${ }^{42}$, and nursing home expenses increase stronger than old-age income, the gap between the corrected and uncorrected aggregate saving rates will increase even further. The estimates in this paper, furthermore, are likely to be only a lower bound, as all individuals in need for long-term care receiving ambulant treatment are not explicitly considered here, and individuals, who receive ambulant care, are most likely to be underrepresented in the EVS. The costs for ambulant care can be as high as those for the care in nursing homes, which leads to an increase of the estimated effect.

\section{Conclusion}

This paper contributes to a better understanding of the saving puzzle in old-age. Almost all empirical investigations in many countries revealed positive or at least close to zero saving rates in old-age. Many suggestions were made to find an explanation for these empirical facts. An often mentioned but never investigated conceptual aspect of the estimation of saving rates in old-age is that institutionalized individuals, especially the nursing home population, are not sampled in almost all studies. This paper sheds more light on the effect of the exclusion of institutionalized individuals in estimating saving rates over old-age. Particularly this group is expected to decumulate wealth since nursing home expenses net of private (and public) insurance exceed disposable income on average. This paper quantifies this effect using the Health and Retirement Study (HRS) for the USA and the German Income and Expenditure Survey (EVS) for Germany.

\footnotetext{
${ }^{42}$ Due to the aging of the population, the number of nursing home residents increases. Because social long-term care benefits are financed by a pay-as-you-go system, real social long-term care benefits have to decrease to prevent that insurance contributions increase. Since the introduction of the long-term care insurance in 1996 until 2008 , there was no increase of benefits for nursing home care.
} 
Evidence in the USA suggests that nursing home residents and the risk of long-term care in a nursing home are key components in understanding the saving behavior in old-age. In the USA, singles deplete their wealth almost completely over a two-year period based on the ratio of medians measure. It takes less than 7 years if dissaving is measured via the median of individual changes and 11 years for the ratio of means. For couples, wealth reduction is not that large. The strong dissaving and the low median wealth holdings are the reasons why 35\% (2004) of all nursing home expenses have to be financed by Medicaid, which supports individuals and families who cannot afford living in a nursing home any more. Since the nursing home population almost increases exponentially with age and reaches more than $30 \%$ at age 95+ for USA, leaving out nursing home residents leads to a serious overestimation of the saving rates in old-age. In the USA, not including the institutionalized households leads to an overestimation of the mean (median) saving rates of 3.3pp (4.3pp) at age 80, 5.4pp (9.4pp) at age 90 and even more for age $90+$.

Based on detailed calculations using the German Income and Expenditure Survey (EVS) and other data sources, the overestimation of the German mean saving rate increases to around $6 \mathrm{pp}$ at age 90 . Therefore, the overestimation of saving rates is not restricted to the USA.

This study helps to explain the high saving rates in old-age found in many countries and adds further credibility to an extended LCH-PIH model, which includes a precautionary saving motive with respect to nursing home risk. The ongoing aging of the industrialized populations and the connected increase in the fraction of the nursing home population will strengthen the importance of including the nursing home population to estimate saving rates in micro empirical studies. Based on calculations for Germany, not including the institutionalized population results in an overestimation of aggregate saving rates of $0.2 \mathrm{pp}$ in 1999 and will increase to around $0.7-0.8 \mathrm{pp}$ in the year 2050. To sum up, more effort should be put in the collection of data including nursing home residents over different countries as done in the HRS. Leaving them out could lead to serious biases as pointed out in this paper based on the saving rate. 


\section{Literature}

Alessie, R., AND A. KEPTEYN (2003): "Savings and Pension in the Netherlands," in: Börsch-Supan, A. (eds): "Life-Cycle Savings and Public Policy - A Cross-National Study of Six Countries," New York: Academic Press, 205-255

AmeriKs, J., A. Caplin, S. Laufer, AND S. VAn Nieuwerburgh (2010): “The Joy of Giving or Assisted Living? Using Strategic Surveys to Separate Public Care Aversion from Bequest Motives," Journal of Finance, Forthcoming.

AnN ARbor, M. I. (2010): "Health and Retirement Study," (RAND HRS Data File (v.J)) public use dataset. Produced and distributed by the University of Michigan with funding from the National Institute on Aging (grant number NIA U01AG009740).

Attanasio, O. P., AND H. W. Hoynes (2000): "Differential Mortality and Wealth Accumulation," Journal of the European Economic Association, 1(4), 821-850.

Attanasio, O. P., AND M. Paiella (2003): "Household Saving Behavior and Pension Policies in the United States," in: Börsch-Supan, A. (eds): "Life-Cycle Savings and Public Policy - A Cross-National Study of Six Countries," New York: Academic Press, 315-402.

Augurzky, B., S. Krolop, R. Mennicken, H. Schmidt, H. Schmitz, AND S. Terkatz (2007): "Pflegeheim Rating Report 2007 - Wachstum und Restrukturierung,“RWI: Essen. RWI Materialien 39.

BANKS, J., AND S. ROHWEDDER (2003): "Pension and Life-Cycle Savings Profiles in the UK," in: Börsch-Supan, A. (eds): "Life-Cycle Savings and Public Policy - A Cross-National Study of Six Countries," New York: Academic Press, 257-313.

BKK-BUNDESVERBANDS (eds) (2003): “Investitionskosten 2003,” bundesweite Pflegedatenbank PAULA.

BÖRSCH-SUPAN, A. (1989): “A Dynamic Analysis of Household Dissolution and Living Arrangement Transitions by Elderly Americans," in: Wise, D. (eds): "Issues in the Economics of Aging," Chicago: University of Chicago Press.

Börsch-Supan, A., A. ReIl-Held, AND R. Schnabel (2003): "Household Saving in Germany," in: BörschSupan, A. (eds): "Life-Cycle Savings and Public Policy - A Cross-National Study of Six Countries," New York: Academic Press, 57-99.

BÖrsch-Supan, A., AND K. Stahl (1991): "Life-Cycle Savings and Consumption Constraints," Journal of Population Economics, 4, 233-255.

BRANDOLINI, A., AND L. CANNARI (1994): "Methodological appendix: the Bank of Italy's Survey of Housheold Income and Wealth," in: Ando, A., L. Guiso, and I. Visco (eds): "Saving and the Accumulation of Wealth. Essays on Households and Government Saving Behavior," Cambridge: Cambridge University Press.

BROWN, J. R., AND A. FINKELSTEIN (2007): "Why is the market for long-term care insurance so small?" Journal of Public Economics, 91, 1967-1991.

BRown, J. R., AND A. FinKELSTEIN (2008): “The Interaction of Public and Private Insurance - Medicaid and the Long-Term Care Insuance Market,” American Economic Review, 98(3), 1083-1102.

Brugiavini, A., AND M. Padula (2003): "Household Saving Behavior and Pension Policies in Italy," in: Börsch-Supan, A. (eds): "Life-Cycle Savings and Public Policy - A Cross-National Study of Six Countries," New York: Academic Press, 101-148. 
Brugiavini, A., AND G. Weber (2003): "Household Savings: Concepts and Measurement," in: Börsch-Supan, A. (eds): "Life-Cycle Savings and Public Policy - A Cross-National Study of Six Countries," New York: Academic Press, 33-55.

DeuTSCHE BundeSBANK (2010): "Zeitreihe JJA327: VGR-D-Ges, Konto der privaten Haushalte, Sparquote," http://www.bundesbank.de/statistik/statistik_zeitreihen.php?lang=de\&open=konjunktur\&func=row\&tr=JJA327

Congressional Budget OfFICE (2004): "Financing Long-Term Care for the Elderly," Government Printing Office: Washington, DC. April.

DE NARDI, M., E. FRENCH, AND J. B. JONES (2010): "Why do the elderly save? The role of medical expenses," Journal of Political Economy, 118(1), 39-75.

ENSTE, D., AND J. PIMPERTZ (2008): "Wertschöpfungs- und Beschäftigungspotenziale auf dem Pflegemarkt in Deutschland bis 2050," IW-Trends, 35. Jahrgang, Heft 4/2008; ISSN 0941-6838.

FALL, M., C. LOISY, AND G. TALON (2003): "An empirical analysis of household savings in France 1984-1998," Research in Economics, 55, 155-172.

FORSCHUNGSDATENZENTRUMS DER STATISTISCHEN ÄMTER DES BUNDES UND DER LÄNDER, care statistic, 1999 and 2003, own calculations.

Frick, J., J. Goebel, M. GrabKa, O. Groh-SAmberg, AND G. WAGner (2007): „Zur Erfassung von Einkommen und Vermögen in Haushaltssurveys: Hocheinkommensstichprobe und Vermögensbilanz im SOEP,“ Data Documentation 19, DIW Berlin.

Friedman, M. (1957): “A Theory of the Consumption Function.” Princeton: Princeton University Press.

Genworth FinAnCial (eds) (2006): "Cost of Care Survey - Nursing Homes, Assisted Living Facilities and Home Care Providers."

Genworth FinAncial (eds) (2007): "Cost of Care Survey - Home Care Providers, Assisted Living Facilities and Nursing Homes."

Genworth Financial (eds) (2008): "Cost of Care Survey - Home Care Providers, Adult Day Health Care Facilities, Assisted Living Facilities and Nursing Homes."

GILBERG, R. (2000): "Hilfe- und Pflegebedürftigkeit im höheren Alter. Eine Analyse des Bedarfs und der Inanspruchnahme von Hilfeleistungen, “Studien und Berichte, 68, Max-Planck-Institut für Bildungsforschung.

HorIOKA, C. Y. (2009): "The (Dis)saving Behavior of the Aged in Japan," ISER Discussion Paper 0763, Institute of Social and Economic Research, Osaka University.

HURD, M. (1987): “Savings of the elderly and desired bequests,” American Economic Review, 77, $298-312$.

HURD, M. (1989): “Mortality risks and bequests,” Econometrica, 57, 779-813.

HuRD, M. (1990): "Research on the Elderly: Economic Status, Retirement, and Consumption and Saving." Journal of Economic Literature, 28(2), 565-637.

HURD, M., AND S. ROHWEDDER (2006): "Economic well-being at older ages: income- and consumption based poverty measures in the HRS," RAND, Working Paper no. WR-410.

Hurd, M., AND S. RoHwedDER (2009): "Methodological Innovations in Collecting Spending Data: The HRS Consumption and Activities Mail Survey," Fiscal Studies, Institute for Fiscal Studies, 30(Special I), 435-459.

Hurd, M., AND S. RoHwedder (2010): "Wealth Dynamics and Active Saving at Older Ages: Do They Add Up?" RAND, mimeo. 
JiAnakoplos, N., P. Ammon, L. MenchiK, AND F. O. IRVIne (1989): "Using panel data to assess the bias in cross-sectional inferences of life-cycle changes in the level of consumption of household wealth," in: Lipsey, R. E., and H. S. Tice (eds): "The measurement of saving, investment and wealth," Chicago: University of Chicago Press.

Jones, A. L., L. L. Dwyer, A. R. Bercovitz, AND G. W. Strahan (2009): “The National Nursing Home Survey: 2004 overview," National Center for Health Statistics, Vital Health Stat, 13(167).

JUSTER, F., J. SMITH, AND F. STAFFORD (1999): “The measurement and structure of household wealth," Labour Economics, 6, 253-275.

KASSNER, E., AND L. SHIREY (2002): "Medicaid Financial Eligibility for Older People: State Variations in Access to Home and Community-Based Waiver and Nursing Home Services," Washington, DC: AARP Public Policy Institute, April 2000-06.

Kitamura, Y., N. TAKayama, And F. Arita (2003): "Household Savings and Wealth Distribution in Japan," in: Börsch-Supan, A. (eds): "Life-Cycle Savings and Public Policy - A Cross-National Study of Six Countries," New York: Academic Press, 149-203.

Krauss, N. A., AND B. M. Altman (1998): "Characteristics of nursing home residents", Rockville (MD): Agency for Health Care Policy and Research - 1996; MEPS Research Findings No. 5, AHCPR Pub. No. 990006 .

KRUG, W., AND G. REH (1992): „Pflegebedürftige in Heimen - Statistische Erhebungen und Ergebnisse,” Schriftenreihe des Bundesministeriums für Familie und Senioren, Band 4, Verlag W. Kohlhammer, Stuttgart, Berlin, Köln.

Lakdawalla, D., D. P. Goldman, J. Bhattacharya, M. Hurd, G. F. Joyce, and C. W. A. Panis (2003): "Forecasting the Nursing Home Population," Medical Care, 41(1), 8-20.

Marshall, S., K. M. MCGarry, AND J. S. SkInNer (2010): “The Risk of Out-of-Pocket Health Care Expenditure at End of Life," NBER Working Paper No. 16170.

MerLis, M. (2003): "Private Long-Term Care Insurance: Who should Buy It and What Should They Buy?" Prepared for the Kaiser Family Foundation, Publication Number: 6072.

MOdigliani, F., AND R. BRUMBERG (1954): "Utility analysis and the consumption function: An interpretation of cross-section data," in: Flavell, J. H., and L. Ross (eds): "Social Cognitive Development Frontiers and Possible Futures," Cambridge, NY: University Press.

Norton, E. C. (2000): “Long-Term Care,” in: Culyer, A. J., and J. P. Newhouse (eds): "Handbook of Health Economics,” Vol. 1, Amsterdam: Elsevier Science, 955-94.

OECD (2005): “The OECD Health Project - Long-term Care for Older People," Complete Edition - ISBN 9264008489, 1- 140.

OXford AnAlytica (2007): "How Will Boomers Pay For Long-Term Care?" July 20, 2007. Posted at http://www.forbes.com/2007/07/19//ongterm-health-care-biz-cx_0720oxford.html.

PALUMBO, M. (1999): "Uncertain medical expenses and precautionary saving near the end of the life-cycle," Review of Economic Studies, 66, 395-421.

RHOADES, J., AND J. SOMMERS (2000): “Expenses and sources of payment for nursing home residents,” Rockville (MD): Agency for Healthcare Research and Quality - 1996; MEPS Research Findings No. 13, AHRQ Pub. No. 01-0010.

Ribbe, W.M., G. Ljunggren, K. Steel, E. Topinkova, ET AL. (1997): "Nursing homes in 10 nations: a comparison between countries and seetings," Age and Ageing, 26-S2, 3-12.

RoHwedDER, S., S. J. HAIDER, AND M. HuRd (2004): "Increases in wealth among the elderly in the early 1990s: How much is due to survey design?” Working Paper 10862, National Bureau of Economic Research. 
Rohwedder, S., M. Hurd, P. PANtoja, AND P. StClair (2005): “Tax Calculations for HRS 2000 \& 2002 Documentation," RAND, Version A, June 2005.

RothGANG, H. (2001): "Finanzwirtschaftliche und strukturelle Entwicklungen in der Pflegeversicherung bis 2040 und mögliche alternative Konzepte.” Expertise für die Enquete-Kommission „Demographischer Wandel“ des Deutschen Bundestages, Bremen.

Schnabel, R. (2007): “Zukunft der Pflege,” Studie im Auftrag der Initiative Neue Soziale Marktwitschaft, Köln.

SCHNEEKLOTH, U. (2006): "Hilfe- und Pflegebedürftige in Alteneinrichtungen 2005," Schnellbericht zur Repräsentativerhebung im Forschungsprojekt „Möglichkeiten und Grenzen selbständiger Lebensführung in Einrichtungen“ (MuG IV) im Auftrag des Bundesministeriums für Familie, Senioren, Frauen und Jugend.

SCHNEEKLOTH, U., AND U. MÜlLER (1997): "Hilfe- und Pflegebedürftige in Heimen. Endbericht zur Repräsentativerhebung im Forschungsprojekt Möglichkeiten und Grenzen selbständiger Lebensführung in Einrichtungen," Schriftenreihe des Bundesministeriums für Familie, Senioren, Frauen und Jugend, Band 147.2.

SHORROCKS, A.F. (1975): "The age-wealth relationship: a cross-section and a cohort analysis," The Review of Economics and Statistics, 57(2), 155-163.

SOMMER, M. (2005): “Trends in German households' portfolio behavior - assessing the importance of age- and cohort-effects," MEA discussion paper, 82-2005.

SOMMER, M. (2008): "Imputation and harmonization of income, consumption, savings and wealth data from the German Income and Expenditure Survey,” mimeo, University of Mannheim.

SPIEß, C. K., AND G. WAGNER (1993): "Re-Regulierung des Marktes für Altenpflege erforderlich," Wochenbericht des Deutsches Institut für Wirtschaftsforschung, 31, 419-422.

STATACORP. (2007): “Stata base reference manual,” vol. 2, I-P, release 10, 206-215.

Statistisches BundeSAMt Deutschland (eds) (2001): „Pflegestatistik 1999 - Pflege im Rahmen der Pflegeversicherung - Deutschlandergebnisse, “ Bonn.

Statistisches Bundesamt Deutschland (eds) (2001): „Pflegestatistik 1999 - Pflege im Rahmen der Pflegeversicherung - Ländervergleich: Pflegeheime,“Bonn.

StATISTISCHES BundeSAMT DeutsChLAND (eds) (2002): „Sonderbericht: Lebenslagen der Pflegebedürftigen Pflege im Rahmen der Pflegeversicherung. Deutschlandergebnisse des Mikrozensus 1999,“Bonn.

StATistisches BundeSAMT DeUTSCHLAND (eds) (2003): „Pflegestatistik 2001 - Pflege im Rahmen der Pflegeversicherung - Deutschlandergebnisse, “Bonn.

Statistisches Bundesamt Deutschland (eds) (2004): „Sonderbericht: Lebenslagen der Pflegebedürftigen Pflege im Rahmen der Pflegeversicherung. Deutschlandergebnisse des Mikrozensus 2003,“ Bonn.

Statistisches Bundesamt Deutschland (eds) (2005): „Pflegestatistik 2003 - Pflege im Rahmen der Pflegeversicherung - Deutschlandergebnisse,“ Bonn.

StATISTISCHES BundeSAMT DEUTSCHLAND (eds) (2005): „Pflegestatistik 2003 - Pflege im Rahmen der Pflegeversicherung - Ländervergleich: Pflegeheime,“ Bonn.

Statistisches Bundesamt Deutschland (eds) (2007): „Pflegestatistik 2005 - Pflege im Rahmen der Pflegeversicherung - Deutschlandergebnisse, “Wiesbaden.

Statistisches Bundesamt Deutschland (eds) (2008): „Pflegestatistik 2007 - Pflege im Rahmen der Pflegeversicherung - Deutschlandergebnisse, “Wiesbaden.

StATistisches Bundesamt DeUtSchland (eds) (2010): "Ergebnisse der $12 . \quad$ koordinierten Bevölkerungsvorausberechnung (Basis: 31.12.2008),“Wiesbaden.

ST.CLAIR, P. ET AL. (2010): RAND HRS Data Documentation (Version J). 
StOne, J. L. (2002): "Medicaid: Eligibility for the Aged and Disabled," CRS Report for Congress RL31413. Penny Hill Press, July 5.

U.S. Census Bureau, Population Division (2010): “Table 1. Annual Estimates of the Resident Population by Sex and Five-Year Age Groups for the United States: April 1, 2000 to July 1, 2009 (NC-EST2009-01),” Release Date: June 2010.

YAARI, M. E. (1965): "Uncertain lifetime, life insurance and the theory of the consumer," Review of Economic Studies, 32(1), 137-150. 


\section{Appendix A: Concepts to measure saving}

Three methods of calculating saving in period $t$ are introduced since they are used by the studies introduced in section 2 and two of these methods are used in this study as well. ${ }^{43}$ For a detailed description of concepts and measurement of household saving rates see Brugiavini and Weber (2003).

1. saving $_{\mathrm{t}}=$ assets $_{\mathrm{t}}-$ assets $_{\mathrm{t}-1}$

2. saving $_{t}=$ income $_{t}-$ consumption $_{t}($ often called residual measure $)$

3. saving $_{t}=$ inflows $_{t}-$ outflows $_{t}$ of the wealth account

Most studies introduced in section 2 use method 1 and/ or 2 to calculate saving in period t. Each of these two methods has certain advantages and disadvantages.

- Consumption measures are often based on recall (Hurd and Rohwedder, 2009). The longer the recall period, the larger the recall bias. Overall consumption seems to be underreported. In addition, there is evidence that income is underreported as well. However, the mismeasurement is more severe related to consumption (Brandolini and Cannari, 1994).

- Wealth holdings are also measured with error. Frick et al. (2007, figures 8, 13) report that financial wealth is underestimated in survey data. Debt and real estate seems to reflect aggregate numbers very well. Juster, Smith and Stafford (1999, pp. 257, 260) point out that the number of categories for different asset groups influences overall wealth holdings positively.

- The change in wealth measure includes active and passive saving. The residual saving measure includes only active savings and does not include capital gains and losses. ${ }^{44}$

- The income minus consumption measure does not take into account inheritances. Inter vivos transfers received should be included in the income measure, and inter vivos transfers given away should be part of the consumption measure, which is the case e.g. in the HRS.

\footnotetext{
${ }^{43}$ More details about the implemented saving measures are provided in section 6 and 7.

${ }^{44}$ The difference between measures including only active saving and measures including both active and passive saving could be large due to drastic price changes of assets like stocks or real estate.
} 


\section{Appendix B: Sample restrictions}

\section{Table 12: Sample restrictions}

\begin{tabular}{|c|c|c|c|c|c|c|}
\hline \multirow[b]{2}{*}{ wave } & \multicolumn{4}{|c|}{ respondents } & \multicolumn{2}{|c|}{ households } \\
\hline & (0) & (1) & (2) & (3) & (4) & (5) \\
\hline 1 & 1212,652 & 12,652 & 0 & 0 & 0 & 0 \\
\hline 2 & 19,642 & 19,642 & 0 & 0 & 0 & 0 \\
\hline 3 & 17,991 & 17,991 & 17,991 & 8,353 & 6,502 & 0 \\
\hline 4 & 21,384 & 21,384 & 21,384 & 10,790 & 8,275 & 6,396 \\
\hline 5 & 19,579 & 19,579 & 19,579 & 10,736 & 8,238 & 8,030 \\
\hline 6 & 18,167 & 18,166 & 18,166 & 10,939 & 8,375 & 8,054 \\
\hline 7 & 20,129 & 20,129 & 20,129 & 11,111 & 8,473 & 8,223 \\
\hline 8 & 18,469 & 18,469 & 18,469 & 11,391 & 8,710 & 8,435 \\
\hline 9 & 17,217 & 17,217 & 17,217 & 11,344 & 8,615 & 8,285 \\
\hline Total & 165,230 & 165,229 & 132,935 & 74,664 & 57,188 & 47,423 \\
\hline
\end{tabular}

(0) Includes all respondents over waves 1 to 9.

(1) Exclude hhidpn==22965041 \& wave==6: no strata and weights.

(2) Exclude waves 1 and 2 due to the availability of a consistent nursing home status (available from 1996 on) and a underreporting of AHEAD respondents' wealth in 1994.

(3) Exclude all respondents below 65 years of age at the interview.

(4) Keep only one observation for each household.

(5) Keep only households, which are observed in two subsequent years.

\section{Appendix C: Weighting}

The HRS oversamples Black and Hispanic HRS respondents as well as the number of HRS respondents who are residents of the state of Florida. The household weight is constructed in a way to have the sum of the weights equal the number of households in the population as measured by the March Current Population Survey, which includes living, noninstitutionalized respondents. A household where the only or both respondents are institutionalized, e.g., living in a nursing home at the time of the interview, will have zero household weights for that wave. Since the institutionalized population is the core of this analysis, a way suggested by the HRS staff is to use the weights from the wave prior to institutionalization. ${ }^{45}$ This procedure assures that almost all households have positive weights since nursing home residents are originally not sampled. For 2000 and 2002 additional weights for the institutionalized population are provided. Unfortunately, the weights are only available on an individual level in these two years. This means that these weights cannot be used to consistently weight the sample on a household level from 1996-2008. For further

\footnotetext{
${ }^{45}$ The same approach is chosen by Hurd and Rohwedder (2010).
} 
information about weighting please consult the HRS homepage (http://hrsonline.isr.umich.edu/index.php?p=weightinfo). If weights are used, there is a very limited number of observations (15) where the household has no positive weight before observed as institutionalized household.

\section{Appendix D: Item non-response}

Table 13: Item non-response over different wealth categories

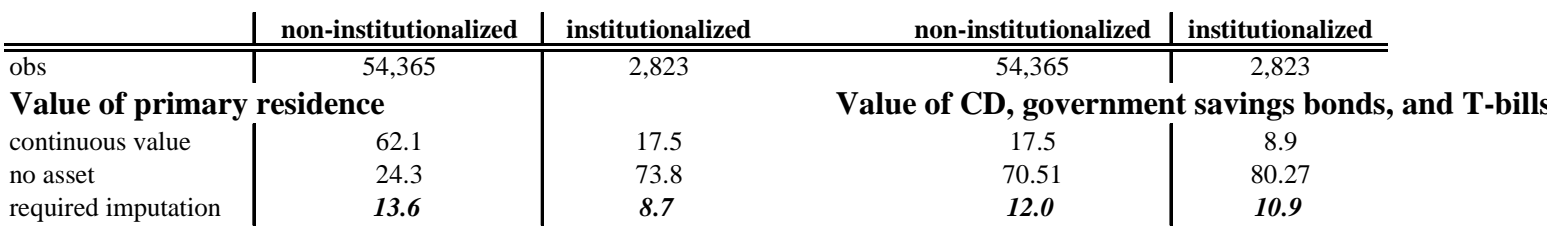

Net value of real estate (not primary residence)

\begin{tabular}{l|l|l} 
continuous value & 10.3 & 3.9
\end{tabular}

\begin{tabular}{l|l|r} 
no asset & 84.8 & 92.7
\end{tabular}

\begin{tabular}{l|l} 
required imputation & 4.9
\end{tabular}

Net value of vehicles

\begin{tabular}{l|l|l} 
continuous value & 57.7 & 13.0
\end{tabular}

\begin{tabular}{l|l|r} 
no asset & 22.7 & 81.1
\end{tabular}

required imputation $\quad 19.6$

Net value of businesses

\begin{tabular}{l|l} 
continuous value & 4.4
\end{tabular}

\begin{tabular}{l|l} 
no asset & 91.7
\end{tabular}

required imputation $\quad 3.9$

Net value of bonds and bond funds

Net value of IRA, Keogh accounts

\begin{tabular}{l|c|c} 
continuous value & 20.5 & 3.9 \\
no asset & 67.1 & 88.6 \\
required imputation & $\mathbf{1 2 . 4}$ & $\mathbf{7 . 6}$
\end{tabular}

Net value of stocks, mutual funds, and investment trusts

\begin{tabular}{l|l|l} 
continuous value & 16.9 & 7.8
\end{tabular}

\begin{tabular}{l|l|r} 
no asset & 69.5 & 80.7 \\
required imputation & $\mathbf{1 3 . 7}$ & $\mathbf{1 1 . 5}$
\end{tabular}

Value of checking, savings, or money market accounts

\begin{tabular}{l|l|l} 
continuous value & 58.2 & 41.3 \\
no asset & 15.3 & 36.4 \\
required imputation & $\mathbf{2 6 . 5}$ & $\mathbf{2 2 . 2}$
\end{tabular}

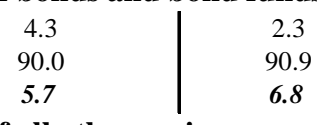

Net value of all other savings

\begin{tabular}{l|c}
8.9 & 3.5 \\
85.6 & 91.9 \\
$\mathbf{5 . 5}$ & $\mathbf{4 . 6}$
\end{tabular}

Value of all mortgages (primary residence)

\begin{tabular}{l|c}
14.7 & 1.9 \\
81.1 & 94.4 \\
$\mathbf{4 . 3}$ & $\mathbf{3 . 7}$
\end{tabular}

Value of other home loans (primary residence)

\begin{tabular}{l|c}
4.8 & 0.4 \\
92.7 & 96.1 \\
2.6 & 3.4 \\
er debt & \\
17.0 & 6.3 \\
78.3 & 88.5 \\
4.8 & 5.2
\end{tabular}

\section{Appendix E: Wealth changes of nursing home residents over waves and age classes}

Figure 16 presents the change in wealth over a two-year period for single nursing home residents and nursing home residents with a spouse. The change in wealth is measured according the three measures introduced in subsection 6.1 and displayed for each wave and age class. Table 14 presents the number of observations in each age class. The first age class 
includes all ages from 65-79 to obtain a reasonable sample size. Contrary to singles, most nursing home residents with a spouse are in the lowest age class.

Figure 16: Two-year percent change in wealth of institutionalized individuals
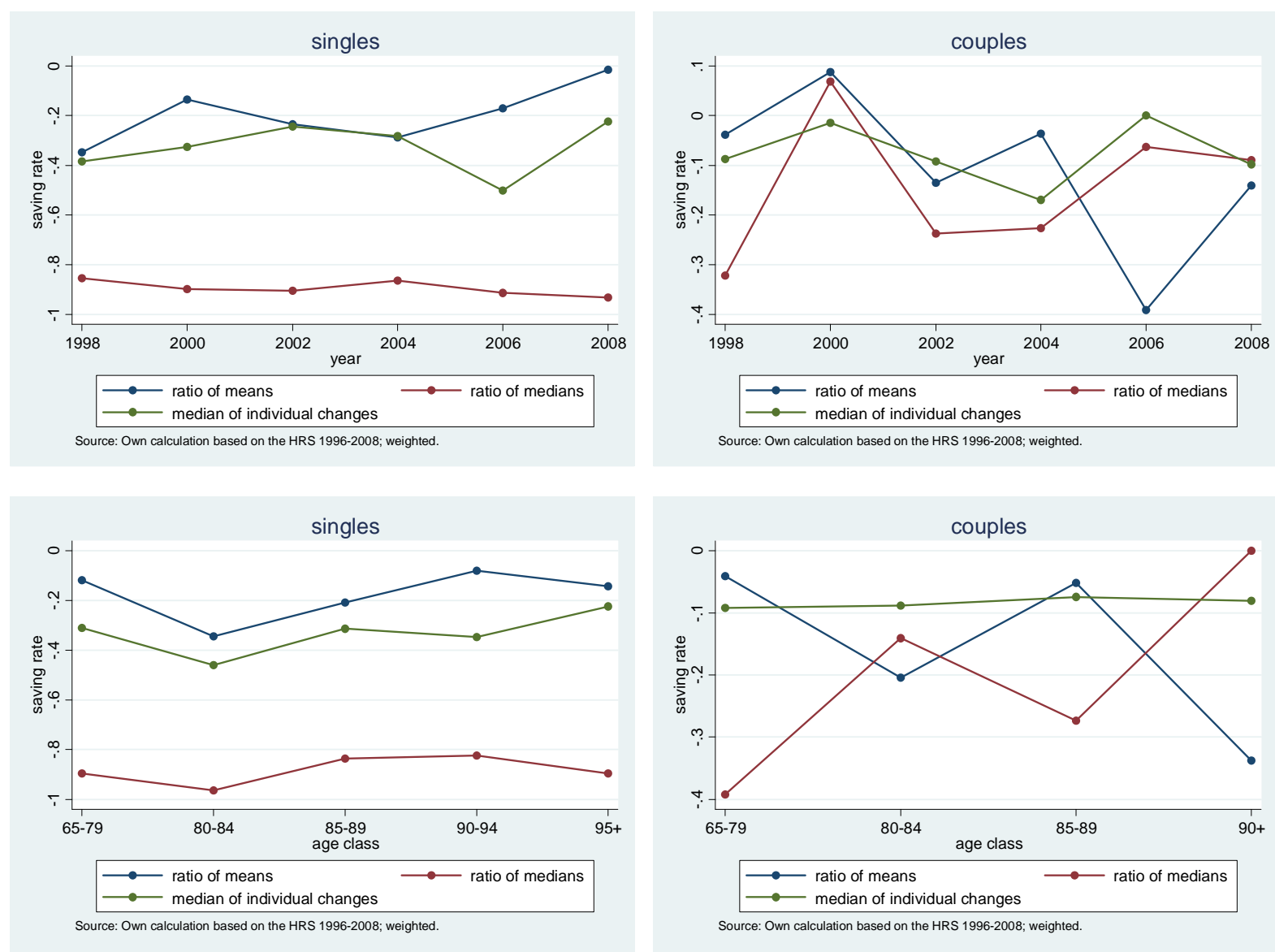

Table 14: Household composition of the institutionalized population over age classes

\begin{tabular}{r|cr|rr|rr} 
& \multicolumn{2}{|c|}{ singles } & \multicolumn{2}{|c|}{ couples } & all households \\
age & obs & in $\%$ & obs & in $\%$ & obs & in \% \\
\hline \hline $65-79$ & 439 & $21 \%$ & 194 & $46 \%$ & 633 & $25 \%$ \\
$80-84$ & 382 & $18 \%$ & 89 & $21 \%$ & 471 & $18 \%$ \\
$85-89$ & 599 & $28 \%$ & 98 & $23 \%$ & 697 & $27 \%$ \\
$90-94$ & 481 & $23 \%$ & 38 & $9 \%$ & 519 & $20 \%$ \\
$95+$ & 222 & $10 \%$ & 7 & $2 \%$ & 229 & $9 \%$ \\
\hline total & 2,123 & $100 \%$ & 426 & $100 \%$ & 2,549 & $100 \%$
\end{tabular}

Source: Own calculation based on the HRS 1996-2008.

Overall, the three measures of two-year percent change in wealth of institutionalized individuals seem to be quite stable for singles over both waves and age classes. For couples, the ratio of means and medians are less stable over waves and age. The mean of individual 
changes is more stable. The lower stability might the due to the lower sample size or influences of the non-institutionalized spouse.

\section{Appendix F: Saving rates for each age and smoothing plots - HRS}

Saving rates are smoothed over age to reduce the variance and to obtain an easy to interpret information structure. The reduction of the variance results in a higher bias. This means a bias/ variance tradeoff is inherent in smoothing. The chosen smoothing procedure is the kernel-weighted local polynomial smoothing (see Stata base reference manual, vol. 2, I-P, release 10, p. 206-215 and the references therein). The chosen specification of the smoothing procedure is displayed below each graph.

\section{Corrected saving rates: all households (including institutionalized households)}
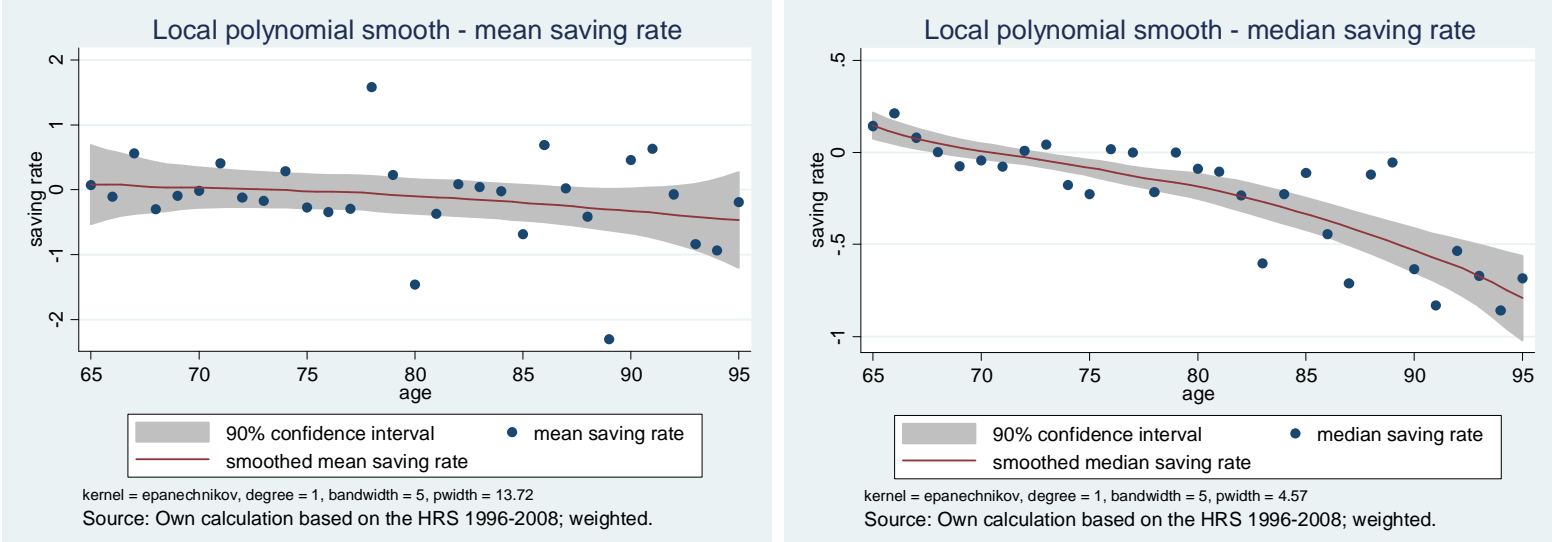

\section{Uncorrected saving rates: Non-institutionalized households}
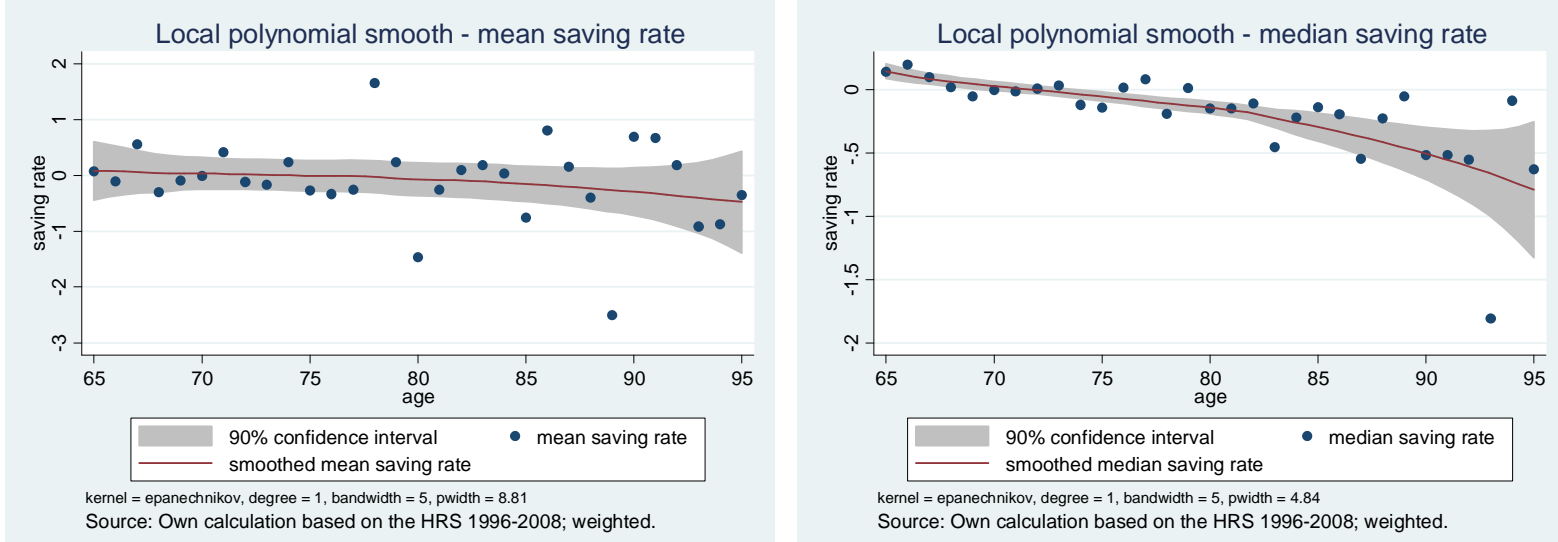


\section{Appendix G: Calculation of nursing home expenses in Germany}

The daily rates for care as well as board and lodgings are taken from the care statistic of the statistical office in 1999 and 2003. Average investment expenses per resident over all federal states are based on the PAULA data base of the BKK-Bundesverband. The daily rates are multiplied by 30.4 to obtain average monthly costs. Columns 1-3 of table 15 show the average care expenses depending on the care level. Column 4 shows the average care expenses over all care levels, weighted according to the fraction of individuals in each care level and federal state.

Columns 5-7 present the net cost of care after the contribution of the long-term care insurance is taken into account. For a few federal states the costs are zero since the contribution of the long-term care insurance is larger compared to the average expenses. Moreover, the contribution of the long-term care insurance is restricted to a maximum of $75 \%$ of the total nursing home expenses. Column 8 displays the weighted average net expenses of care over all care levels. The cost of board and lodging can be seen in column 9 and the investment expenses in column $10{ }^{46}$ Overall net expenses are shown in column 11 . Column 12 presents overall expenses for individuals of care level " 0 ". These individuals do not get a contribution to their cost of care from the long-term care insurance. The costs of care are assumed to be 18.4\% below the expenses for care level one (Schneekloth, 2006, p. 29, table 9.1). Column 13 is the sum of average overall costs including residents of care-level " 0 ". ${ }^{47}$ Column 14 adds an average extra charge for single rooms. ${ }^{48}$

\footnotetext{
${ }^{46}$ The average investment costs per person are taken from the PAULA data base of the BKK-Bundesverband. Only data for 2003 are available. Thus, to obtain investment expenses for 1999, the 2003 data are inflation adjusted assuming the same inflation rate as for the combination of cost of care as well as board and lodging. This is equivalent to assuming the investment expenses reflect a constant fraction of the other expenses.

${ }^{47}$ Column 13 is the sum of column 11 multiplied by $92.6 \%$ (fraction of care level "I-III") for the old federal states and $96.6 \%$ for the newly-formed German states and column 12 times $7.4 \%$ (fraction of care level "0") for the old federal states and 3.4\% for the newly-formed German states. The fraction of care-level "0" nursing home residents is taken from Schneekloth (2006, p. 10, table 2.1).

${ }^{48}$ To the best knowledge of the author, there is no statistic about the additional charge of single rooms in nursing homes available. According to experts and inquiries in the internet, the additional charge is set to $€ 150$ in 2003 and $€ 141$ for 1999 . This additional charge is multiplied by the fraction of available single rooms of $55.4 \%$ in 2003 and 45.7\% in 1999 (care statistic 1999 and 2003), which is a reasonable assumption since 89.2\% (1999) and $89.5 \%$ (2003) of all places in nursing home are taken. The percentages of nursing home utilization even increase if residents of care level "0" are additionally included.
} 
Table 15: Calculation of net nursing home costs in Germany

\begin{tabular}{|c|c|c|c|c|c|c|c|c|c|c|c|c|c|c|}
\hline $\begin{array}{l}1999 \\
\text { federal state }\end{array}$ & $\begin{array}{c}\text { (1) } \\
\text { care level I } \\
\end{array}$ & $\begin{array}{c}\text { (2) } \\
\text { cost of care } \\
\text { care level II } \\
\end{array}$ & $\begin{array}{c}\text { (3) } \\
\text { care level IIII }\end{array}$ & $\begin{array}{c}\text { (4) } \\
\text { average } \\
\text { cost of care } \\
\end{array}$ & $\begin{array}{c}\text { (5) cos } \\
\text { care level I }\end{array}$ & $\begin{array}{l}\text { (6) } \\
\text { of care - bene } \\
\text { care level II }\end{array}$ & $\begin{array}{l}\text { (7) } \\
\text { efit } \\
\text { care level IIII }\end{array}$ & $\begin{array}{c}\text { (8) } \\
\text { average } \\
\text { cost of care }\end{array}$ & $\begin{array}{l}\text { (9) } \\
\text { board \& } \\
\text { lodging }\end{array}$ & $\begin{array}{c}(10) \\
\text { investment } \\
\text { expenses }\end{array}$ & \begin{tabular}{c|}
$(11)$ \\
overall net \\
expenses
\end{tabular} & $\begin{array}{c}(12) \\
\text { overall exp. } \\
\text { care level "0" }\end{array}$ & $\begin{array}{l}\text { (13) } \\
\text { overall exp. } \\
\text { incl. care level "0" }\end{array}$ & $\begin{aligned} &(14) \\
& \text { overall exp. } \\
&+ \text { single room }\end{aligned}$ \\
\hline Baden-Württemberg & $\begin{array}{lr}1,307 \\
\end{array}$ & $1,1,611$ & 2,037 & \begin{tabular}{ll|}
1,588 \\
\end{tabular} & 284 & 332 & 605 & (2) 366 & $\begin{array}{ll}547 \\
\end{array}$ & 309 & " & ㄱ. 1,923 & $\begin{array}{lr}1,274 \\
\end{array}$ & 1,338 \\
\hline Bavaria & 1,277 & 1,642 & 1,854 & 1,584 & 254 & 363 & 422 & 345 & 486 & 242 & 1,073 & 1,771 & 1,125 & 1,189 \\
\hline Berlin & 1,246 & 1,733 & 2,098 & 1,671 & 223 & 454 & 666 & 434 & 456 & 274 & 1,163 & 1,747 & 1,206 & 1,271 \\
\hline Brandenburg & 1,003 & 1,216 & 1,733 & 1,256 & 0 & 0 & 301 & 64 & 426 & 191 & 681 & 1,436 & 707 & 771 \\
\hline Bremen & 1,003 & 1,611 & 2,006 & 1,547 & 0 & 332 & 574 & 303 & 608 & 370 & 1,282 & 1,797 & 1,320 & 1,384 \\
\hline Hamburg & 1,186 & 1,672 & 2,189 & 1,599 & 163 & 393 & 757 & 381 & 669 & 363 & 1,413 & 2,000 & 1,457 & 1,521 \\
\hline Hesse & 1,246 & 1,702 & 2,158 & 1,703 & 223 & 423 & 726 & 454 & 547 & 384 & 1,385 & 1,948 & 1,427 & 1,491 \\
\hline Meckl. Western Pomerania & 1,034 & 1,277 & 1,733 & 1,263 & 11 & 0 & 301 & 56 & 426 & 84 & 565 & 1,353 & 592 & 656 \\
\hline Lower Saxony & 1,125 & 1,459 & 1,854 & 1,464 & 102 & 180 & 422 & 222 & 486 & 397 & 1,105 & 1,802 & 1,157 & 1,221 \\
\hline Northrhine-Westphalia & 1,155 & 1,581 & 2,280 & 1,627 & 132 & 302 & 848 & 386 & 730 & 255 & 1,371 & 1,927 & 1,412 & 1,476 \\
\hline Rhineland Palatinate & 1,216 & 1,550 & 2,098 & 1,570 & 193 & 271 & 666 & 337 & 578 & 283 & 1,198 & 1,853 & 1,247 & 1,311 \\
\hline Saarland & 1,125 & 1,550 & 2,006 & 1,483 & 102 & 271 & 574 & 266 & 578 & 347 & 1,191 & 1,842 & 1,239 & 1,303 \\
\hline Saxony & 942 & 1,186 & 1,642 & 1,162 & 0 & 0 & 210 & 29 & 426 & 234 & 689 & 1,428 & 714 & 778 \\
\hline Saxony-Anhalt & 973 & 1,307 & 1,581 & 1,232 & 0 & 28 & 149 & 39 & 426 & 196 & 661 & 1,416 & 687 & 751 \\
\hline Schleswig-Holstein & 1,094 & 1,398 & 1,733 & 1,360 & 71 & 119 & 301 & 141 & 547 & 319 & 1,007 & 1,760 & 1,063 & 1,127 \\
\hline Thuringia & 821 & 1,125 & 1,520 & 1,105 & 0 & 0 & 88 & 20 & 486 & 108 & 615 & 1,264 & 637 & 701 \\
\hline Germany 1999 & 1,155 & 1,520 & 1,976 & 1,509 & 132 & 241 & 544 & 276 & 547 & 282 & 1,105 & 1,772 & 1,150 & 1,214 \\
\hline
\end{tabular}

\begin{tabular}{|c|c|c|c|c|c|c|c|c|c|c|c|c|c|c|}
\hline $\begin{array}{l}2003 \\
\text { federal state }\end{array}$ & $\begin{array}{c}\text { (1) } \\
\text { care level I }\end{array}$ & $\begin{array}{c}\text { (2) } \\
\text { cost of care } \\
\text { care level II }\end{array}$ & $\begin{array}{c}\text { (3) } \\
\text { care level IIII }\end{array}$ & \begin{tabular}{c|} 
(4) \\
average \\
cost of care
\end{tabular} & 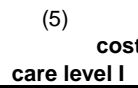 & $\begin{array}{l}(6) \\
\text { of care - bene } \\
\text { care level II }\end{array}$ & $\begin{array}{l}\text { (7) } \\
\text { efit } \\
\text { care level IIII }\end{array}$ & $\begin{array}{c}\text { (8) } \\
\text { average } \\
\text { cost of care }\end{array}$ & $\begin{array}{l}\text { (9) } \\
\text { board \& } \\
\text { lodging }\end{array}$ & $\begin{array}{c}(10) \\
\text { investment } \\
\text { expenses }\end{array}$ & \begin{tabular}{c|}
$(11)$ \\
overall net \\
expenses
\end{tabular} & \begin{tabular}{c|}
$(12)$ \\
overall exp. \\
care level "0"
\end{tabular} & $\begin{array}{l}\text { (13) } \\
\text { overall exp. } \\
\text { incl. care level "0" }\end{array}$ & $\begin{aligned} &(14) \\
& \text { overall exp. } \\
&+ \text { single room }\end{aligned}$ \\
\hline Baden-Württemberg & $\begin{array}{ll}1,398 \\
\end{array}$ & $\begin{array}{ll}1,763 \\
\end{array}$ & $2,2,219$ & $\begin{array}{ll}1,719 \\
\end{array}$ & $\begin{array}{ll}375 \\
\end{array}$ & $\begin{array}{ll}484 \\
\end{array}$ & $\begin{array}{ll}787 \\
\end{array}$ & " 502 & (2578 & 332 & $\begin{array}{lr}1,412 \\
\end{array}$ & 20,051 & $\begin{array}{ll}1,459 \\
\end{array}$ & 101,535 \\
\hline Bavaria & 1,459 & 1,824 & 2,098 & 1,768 & 436 & 545 & 666 & 538 & 517 & 267 & 1,322 & 1,975 & 1,370 & 1,446 \\
\hline Berlin & 1,368 & 1,885 & 2,250 & 1,817 & 345 & 606 & 818 & 579 & 486 & 296 & 1,361 & 1,899 & 1,401 & 1,477 \\
\hline Brandenburg & 1,094 & 1,368 & 1,885 & 1,403 & 71 & 89 & 453 & 166 & 456 & 212 & 834 & 1,561 & 858 & 934 \\
\hline Bremen & 1,064 & 1,702 & 2,158 & 1,648 & 41 & 423 & 726 & 399 & 669 & 398 & 1,466 & 1,935 & 1,501 & 1,576 \\
\hline Hamburg & 1,277 & 1,763 & 2,310 & 1,692 & 254 & 484 & 878 & 475 & 669 & 378 & 1,522 & 2,089 & 1,564 & 1,640 \\
\hline Hesse & 1,246 & 1,733 & 2,219 & 1,691 & 223 & 454 & 787 & 459 & 517 & 377 & 1,352 & 1,911 & 1,393 & 1,469 \\
\hline Meckl. Western Pomerania & 1,034 & 1,368 & 1,794 & 1,335 & 11 & 89 & 362 & 115 & 456 & 89 & 659 & 1,388 & 684 & 760 \\
\hline Lower Saxony & 1,216 & 1,581 & 1,976 & 1,548 & 193 & 302 & 544 & 322 & 486 & 415 & 1,222 & 1,893 & 1,272 & 1,348 \\
\hline Northrhine-Westphalia & 1,216 & 1,702 & 2,250 & 1,645 & 193 & 423 & 818 & 423 & 760 & 260 & 1,443 & 2,013 & 1,485 & 1,561 \\
\hline Rhineland Palatinate & 1,186 & 1,550 & 2,128 & 1,521 & 163 & 271 & 696 & 309 & 608 & 281 & 1,198 & 1,857 & 1,246 & 1,322 \\
\hline Saarland & 1,125 & 1,581 & 2,098 & 1,493 & 102 & 302 & 666 & 288 & 578 & 348 & 1,214 & 1,844 & 1,260 & 1,336 \\
\hline Saxony & 1,003 & 1,277 & 1,733 & 1,241 & 0 & 0 & 301 & 41 & 426 & 245 & 712 & 1,490 & 738 & 814 \\
\hline Saxony-Anhalt & 1,094 & 1,459 & 1,702 & 1,392 & 71 & 180 & 270 & 164 & 486 & 222 & 873 & 1,602 & 897 & 973 \\
\hline Schleswig-Holstein & 1,338 & 1,672 & 2,037 & 1,629 & 315 & 393 & 605 & 410 & 608 & 374 & 1,393 & 2,074 & 1,443 & 1,519 \\
\hline $\begin{array}{l}\text { Thuringia } \\
\text {. }\end{array}$ & 942 & 1,277 & 1,702 & 1,260 & 0 & 0 & 270 & $\begin{array}{r}62 \\
\end{array}$ & 547 & 123 & 731 & 1,439 & 755 & 831 \\
\hline Germany 2003 & 1,246 & 1,672 & 2,098 & 1,616 & 223 & 393 & 666 & 393 & 578 & 301 & 1,271 & 1,895 & 1,317 & 1,392 \\
\hline
\end{tabular}




\section{Appendix H: Suitability of other German datasets}

The German SAVE study (Sparen und Altersvorsorge in Deutschland) has reached its maximum sample size in 2006. However, the sample size is still too small to calculate robust saving rates in old-age (age 65-69: 313 households; age 70-74: 273 households; age 75-79: 151 households; age 80-84: 67 households; age 85+: 21 households). No nursing home residents are sampled.

The German SOEP (Socio-Economic Panel Study) lacks sufficient measures of saving. ${ }^{49}$ The question „Do you usually have an amount of money left over at the end of the month that you can save for larger purchases, emergency expenses or to acquire wealth? If yes, how much?“ has certain restrictions: first, it asks for regular saving, and second, it does not allow dissaving. Net wealth differences over a five year horizon (between the surveys 2002 and 2007) can be calculated. The mean net wealth change is negative over all age groups. In addition, mean saving rates over age classes fluctuate a lot and are significantly negative for age groups below 65 . Thus, the measure of net wealth does not seem to be very precise. Nursing home residents are originally not sampled. However, individuals are followed if they move into a nursing home. In 2007, they add up to 42 individuals in a nursing home and 32 individuals in residential homes. The number of nursing home residents is clearly too small.

The Survey of Health, Ageing and Retirement in Europe (SHARE) has one possibility to measure saving using the wealth difference between wave 1 and $2 .^{50}$ Since the individual has to be sampled in both waves, the German sample has an insufficient number of observations (age 65-69: 340 households; age 70-74: 212 households; age 75-79: 146 households; age 8084: 89 households; age 85+: 35 households). Nursing home residents are originally not included in the German sample. Since individuals are followed when moving into a nursing home, the second wave of the German sample contains less than 20 nursing home residents (depending on the variables to construct nursing home residence). Again the number of observations is by far too small.

\footnotetext{
${ }^{49}$ The German SOEP data are provided by German Institute for Economic Research (DIW Berlin).

${ }^{50}$ This analyses uses data from SHARE release 2.3.0, as of November 13th 2009. SHARE data collection in 2004-2007 was primarily funded by the European Commission through its 5th and 6th framework programmes (project numbers QLK6-CT-2001- 00360; RII-CT- 2006-062193; CIT5-CT-2005-028857). Additional funding by the US National Institute on Aging (grant numbers U01 AG09740-13S2; P01 AG005842; P01 AG08291; P30 AG12815; Y1-AG-4553-01; OGHA 04-064; R21 AG025169) as well as by various national sources is gratefully acknowledged (see http://www.share-project.org for a full list of funding institutions).
} 


\section{Appendix I: Saving rates for each age and smoothing plots - EVS}

Saving rates are smoothed over age to reduce the variance and to obtain an easy to interpret information structure. The reduction of the variance results in a higher bias. This means a bias/ variance tradeoff is inherent in smoothing. The chosen smoothing procedure is the kernel-weighted local polynomial smoothing (see Stata base reference manual, vol. 2, I-P, release 10, p. 206-215 and the references therein). The chosen specification of the smoothing procedure is displayed below each graph.
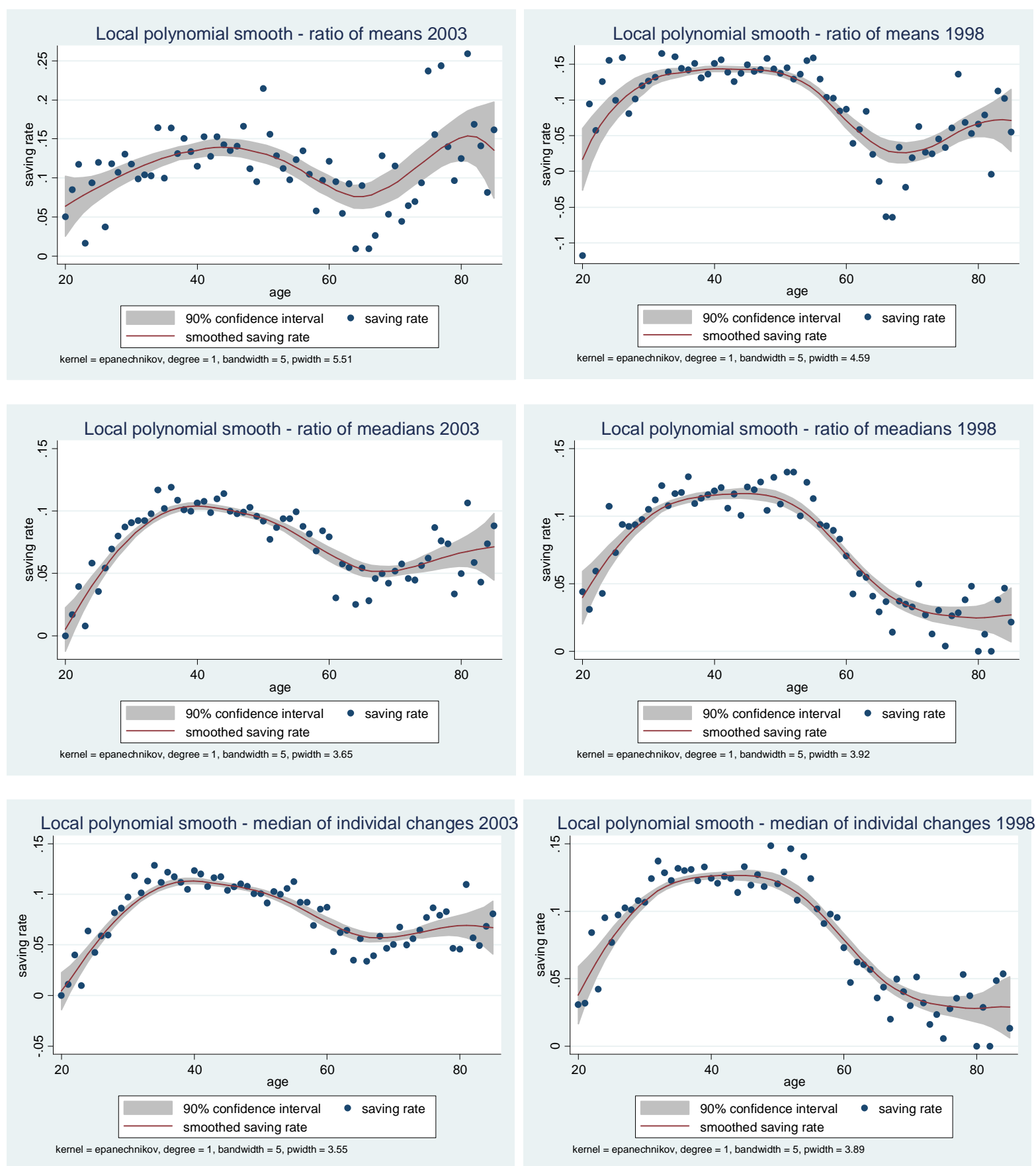


\section{Appendix J: Net wealth over age - EVS}

For all individuals, who are not able to cover net nursing home expenses, mean and median net wealth is calculated over age. The figures below show smoothed median and mean net wealth over age for single males, single females, and married individuals.
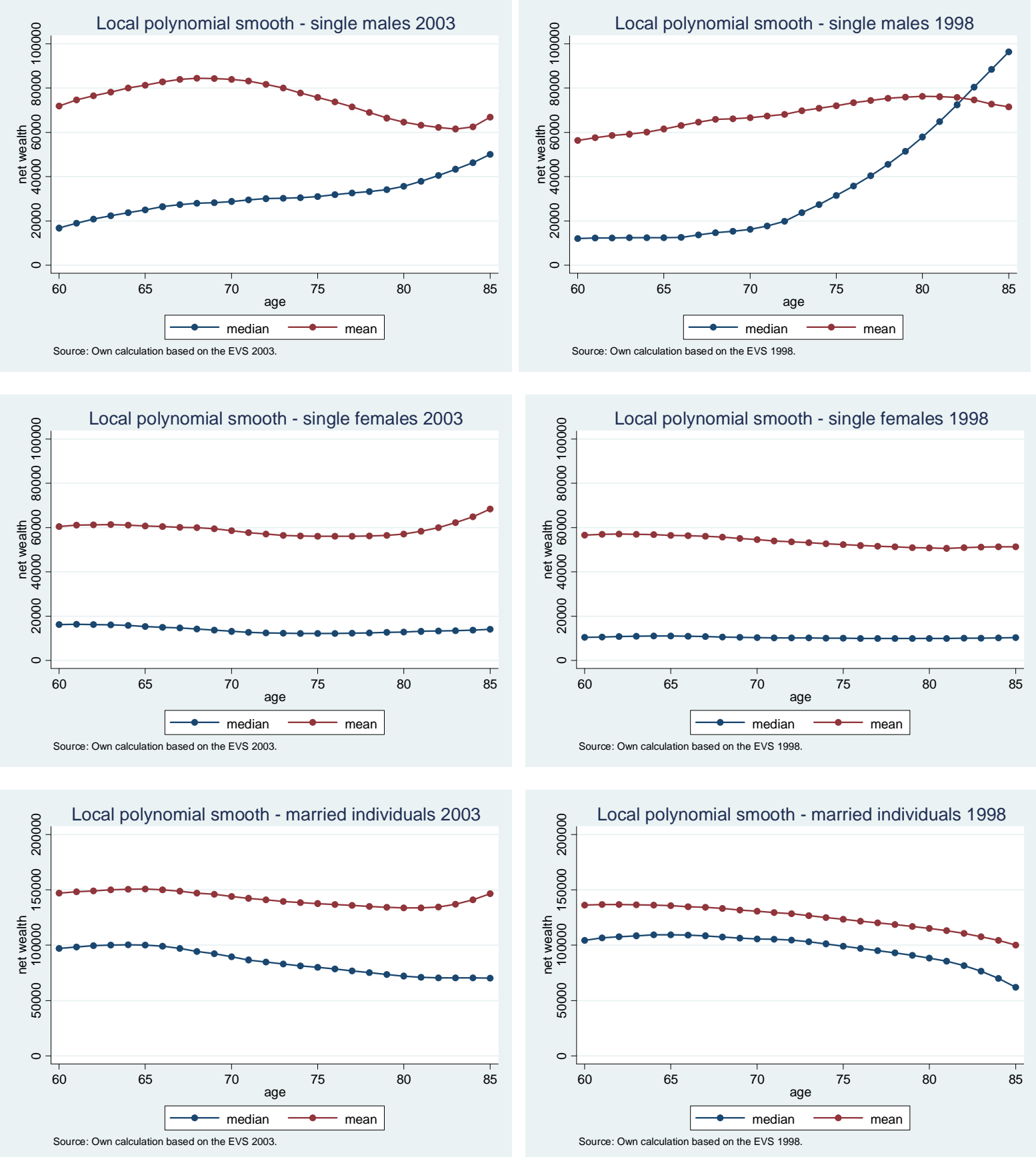